\title{
Solid Transfer in Low Flow Sewers, the Distance Travelled So Far Is Not Enough
}

\author{
Rodney McDermott, Alan Strong, Philip Griffiths \\ Belfast School of Architecture and the Built Environment, Ulster University, Belfast, Northern Ireland \\ Email: r.mcdermott@ulster.ac.uk
}

How to cite this paper: McDermott, R., Strong, A. and Griffiths, P. (2019) Solid Transfer in Low Flow Sewers, the Distance Travelled So Far Is Not Enough. Journal of Environmental Protection, 10, 164-207. https://doi.org/10.4236/jep.2019.102011

Received: December 6, 2018

Accepted: January 27, 2019

Published: January 30, 2019

Copyright $\odot 2019$ by author(s) and Scientific Research Publishing Inc. This work is licensed under the Creative Commons Attribution International License (CC BY 4.0).

http://creativecommons.org/licenses/by/4.0/

(c) (i) Open Access

\begin{abstract}
Sewer blockages are on the increase whilst water closet (WC) flush volumes are on the decrease. Furthermore, Water UK reported figures show that the actual number of properties affected by sewer flooding is on the rise. Sewer blockages can lead to sewer flooding of homes and collapse of sewers which impact negatively on social, economic and environmental factors, and therefore, they are not sustainable. Water conservation is required due to water stress but reduced water use results in less water to waste, which in turn reduces solids' transfer in sewers. When considering reducing water usage through water conservation, these savings could be cancelled out by an increased population and the situation exacerbated by the impacts of climate change. There are issues in relation to varying design methods, a reliance on engineering judgement in sewer design, uncertainty relating to future water stress, and a lack of cross disciplinary design decision-making. Public health engineering solutions are needed to reduce the number of sewer blockages and the environmental impact of sewer flooding. This paper examines the fundamental research that have been carried out in the area of "solid transfer in sewers" resulting from "less water to waste" since the mid-20th Century. Contrary to existing literature, this paper identifies that, now more than ever, this type of research is needed to deal with the increased need for water conservation. To judge that solid transfer research is complete can be compared to supporting a statement that "water conservation is complete".
\end{abstract}

\section{Keywords}

Sewer Blockages, Water Conservation, Low Flows in Sewers

\section{Introduction}

The Environment Agency's (EA) report entitled Less Water to Waste made recommendations [1], including the need for rig-based testing, to investigate 
combinations of optimum pipe types, diameters and gradients for solid movement in low flow situations. The report also called for more informed guidance to ensure that "water efficiency" was analysed whilst also looking at the "bigger picture" in terms of considering sewer design. The Less Water to Waste report came after a number of EA reports that advised on conserving water. This includes the EA's Conserving Water in Buildings: A Practical Guide which provides information on savings that are possible through low-flush water closets and demonstrates that WC flush volumes have steadily decreased over the past 40 years, resulting in less water to waste and ultimately lower flows in sewers [2]. Reduced flush volumes result in reduced distance that solids are transferred along sewer pipes.

Swaffield proposed that adequate research on the topic of solid transport had already been conducted [3] [4]. The statement made by Swaffield had considerable gravitas when considering that Swaffield either conducted or oversaw a significant amount of "low flow" research. This paper addresses the contradiction by providing the context and nature of the research that has been conducted into solid transfer and sewers over the past 44 years. The main findings and recommendations for further work are related to rig-based testing and solid transfer in separate sewers. The literature discussed herein includes work by Wakelin [5], Bokor [6], Lillywhite et al. [7] [8], Butler et al. [9]-[15], Swaffield et al. [3] [4] [16]-[25], Cummings et al. [26] [27] [28], Littlewood [29], Littlewood and Butler [30] [31], Littlewood et al. [32] and Gauley et al. [33] [34]. However, an initial study by Wakelin [5] examined solid transfer in sewers and assists in setting part of the overall scene.

\section{RHM Wakelin}

\subsection{Introduction}

Wakelin conducted a doctoral study under the supervision of J. A. Swaffield at Brunel University [5]. The doctoral thesis referred to in this section (unless stated otherwise) is Wakelin's 1978 doctoral thesis. Swaffield was an eminent scholar in many low flow sewer studies carried out including the supervision of doctoral studies. Wakelin [5] refers to initial studies undertaken by Swaffield [16] which examined solids' transport in above ground sanitary drainage that led to Wakelin's study. Whilst the Wakelin study was being carried out at Brunel, Marriott was also carrying out a doctoral study on Transport of Solids in Reduced Flush Volumes which was also supervised by Swaffield [18].

The study by Wakelin was undertaken primarily due to the research requirements of the Department of Health and Social Security (DHSS) and aimed to address problems in hospital drainage systems [5]. It included rig-based testing and reference is made to the limited amount of previous research in this area. The study used three rigs which included a "straight pipe test-rig" $14.0 \mathrm{~m}$ long with two different pipe types (plastic and cast iron), a "plastic bends test-rig" and a "plastic junctions test-rig". The solids used were maternity pads (18 mm thick, $280 \mathrm{~mm}$ long and $70 \mathrm{~mm}$ wide) and were taken as a worst-case loading. Toilet 
paper sheets were also used in combination with maternity pads to detect multiple solids' transfer.

The following sub-sections (2.2-2.5) outline the findings of the Wakelin study in terms of solid transfer in low flows [5].

\subsection{High Level Cisterns}

Wakelin based his research on two brands of WCs-Armitage Shanks and Twyford and used two pan outlet types of each brand (P-trap and S-trap) [5]. Wakelin also investigated both high and low level cisterns for both brands [5]. In doing so, he pointed to the difference in the pans, i.e. the flush inlet, with the low level WCs having horizontal or back entry flush pipes and the high level WCs having vertical or top entry flush pipes.

According to Wakelin, flush pipe restrictors are used on the flush pipe from high level cisterns in order to limit splashing from the pan [5]. This study also included an investigation of flush restrictors by carrying out tests with and without flush restrictors. The results showed that the Armitage Shanks high level cistern provided a higher mean pan discharge velocity than the low level WC using the same pan type and the manufacturer's recommended flush restrictors. Wakelin reported that the aforementioned tests were carried out on the Armitage Shanks WCs when the flush restrictors were removed. This resulted in a slight decrease in mean pan discharge velocity. Wakelin also reported on problems associated with flush pipe restrictors and the variability in hydraulic performance that can result through using and not using flush pipe restrictors [5].

Wakelin provided the following reason for not carrying out further tests comparing high level and low level cisterns [5]. This was because the DHSS research concluded that "no benefit was gained by the use of high level cisterns" and that, as a result, the further installation of high level cisterns would not be recommended by the DHSS. It is not clear whether the DHSS decision was taken based on previous research carried out by, or commissioned by, the DHSS or whether the decision was based on Wakelin's initial experiments.

\subsection{S-Trap and P-Trap}

Wakelin also compared the Armitage Shanks and Twyford WCs in terms of the standard pan outlet types available which were P-trap and S-trap, with P-trap providing a horizontal outlet from the pan and the S-trap providing a vertical outlet from the pan both occurring after the initial trap [5]. Wakelin concluded that from the tests completed "the P trap wc pans tested were approximately $8 \%$ less efficient than the comparable $S$ trap wc pans" [5].

\subsection{The Effects of Junctions}

Whilst Wakelin looked at both bends and junctions [5], the tests carried out on bends mainly related to connections to vertical stacks within hospital drainage; therefore, the work on junctions is what is mainly considered herein. Wakelin pointed out that considerable effort was made to develop an equation to predict 
solid transfer that included junctions and bends but concluded that, at this point, a universal equation that estimated solid transfer velocity after passing a bend or pipe fitting was not possible [5]. The junction research included a $135^{\circ}$ junction on the straight pipe test-rig which was tested at three different entry angles including horizontal $0^{\circ}, 15^{\circ}$ and $30^{\circ}$ as shown in Figure 1 . A $92.5^{\circ}$ junction was also tested.

Wakelin identified a number of problems associated with the junctions, including water and solids backing-up the main line and solid deposition at the junction [5]. Wakelin concluded that entry angles greater than $0^{\circ}$ (Figure 1) provided fewer disturbances to the flow in the branch that it was entering [5]. Wakelin also made reference to contradictory information that exists on the increased risk of solid deposition relating to entry angles at junctions [5], pointing out that, directly after an on-line pipe fitting (bend, joint or junction), a "rapid solid deceleration" takes place for $1.0-2.0 \mathrm{~m}$ and this is normally followed by a velocity regain. This is dependent on the initial velocity of the solid approaching the fitting. Wakelin [5] also reported that the velocity regain during some of the tests was greater than that which was numerically calculated and "it could therefore be concluded that the inclusion of a bend or junction can improve the solid velocity at a point sufficiently far from the bend". However, this point was later contradicted by Bokor who pointed out that "Wakelin's data was considered less than adequate to assess linear assessment of deceleration" [6]. Bokor disagreed with Wakelin's findings relating to a bend or junction improving solids' velocity and stated that if Wakelin had monitored a greater distance of downstream pipework, "the reduced efficiency of solid transport would have become obvious" as a result of bends or junctions. This implied that a longer test-rig was required [6].

Wakelin concluded that the "effect of pipe fittings can be ignored in the designed system" if the bend is positioned a minimum of $5.0 \mathrm{~m}$ beyond the commencement of what Wakelin refers to as Zone 3 flow conditions [5]. Bridge explained that modelling the effect of junctions in pipelines has increased complexity due to the backwater effects [35]. Bridge supports Wakelin's findings when considering bends and concludes through experiments that there was " $n o$ noticeable effect on either the wave depth or wave velocity upstream or downstream from the bend" [35]. Bridge used the Wallingford storm sewer model as a supporting example, as this model does not consider bends as "their influence was found to be unimportant" [35]. In the hydrologic model section of the literature review, Bridge makes reference to the Wallingford example and used junction as opposed to bend [35]. Bridge also looked at level invert junctions and recommended that further work be carried out on junctions and, in particular, on non-level junctions to find the impact on solid transport [35].

Subsequently, Littlewood recommended that further research was required to investigate bends and joints [29]. This suggests that a gap exists in the research area of the effect of bends, joints and junctions on solid transfer in sewers. Such a gap is further supported by Jack and Swaffield who, when discussing junctions 

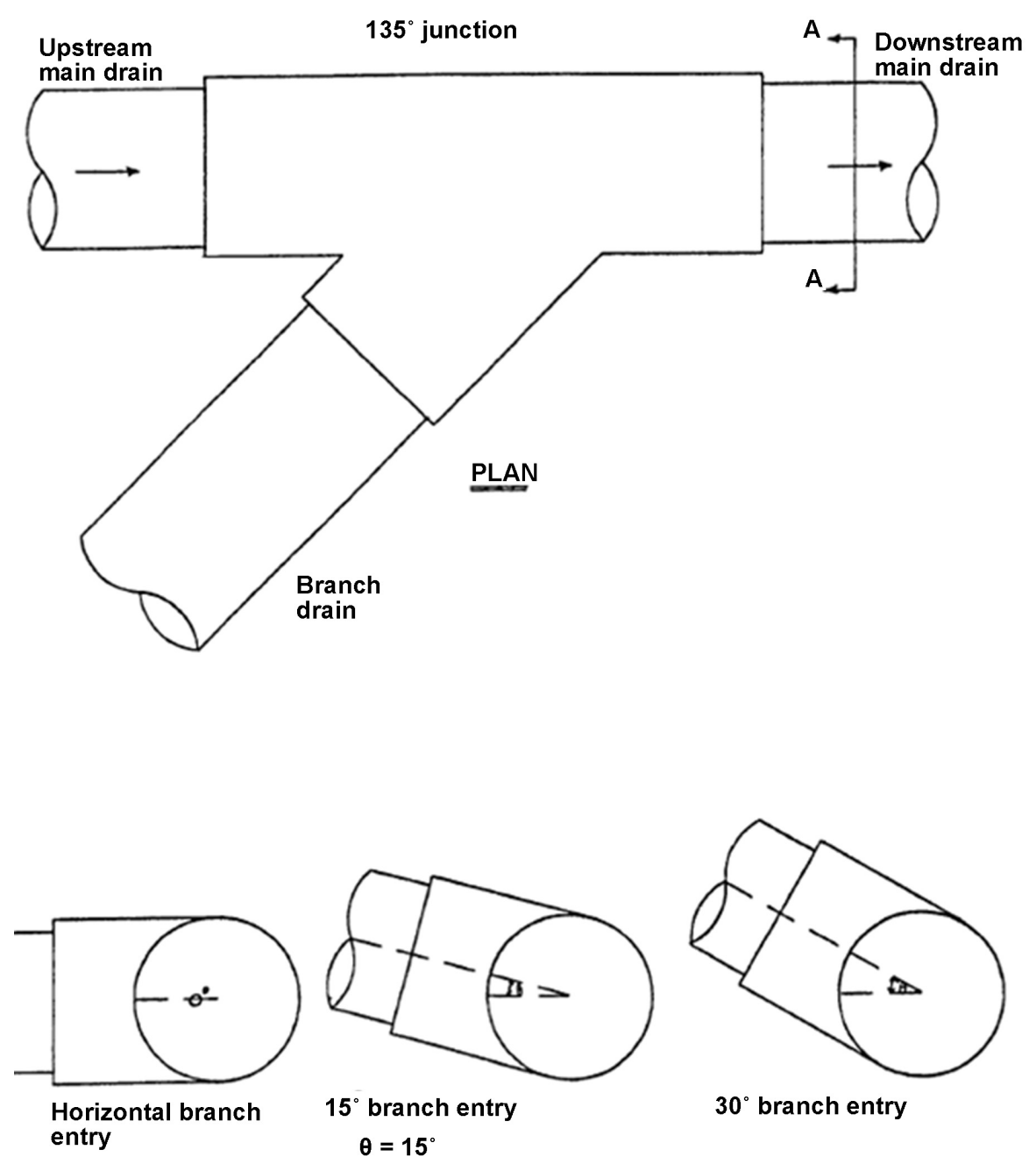

$30^{\circ}$ branch entry

SECTIONS AA

Figure 1. Junction plan and section [5].

in pipelines, referred to the need for predefined boundary conditions when using models to predict solid deposition [36].

\subsection{Effect of WC Venting}

Wakelin concluded that venting of the pipeline did not show any significant changes in solid transfer [5]. This statement was based on the results from the vented and unvented experiments analysed, using "least squares". In contrast, Bokor did not consider the use of least squares as appropriate [6] and reanalysed Wakelin's data for the vented and unvented experiments and concluded that the effect of venting may be connected with the WC pan design and further research was required [5]. Bokor [6] also pointed out that the venting system adopted by Wakelin for the P-trap and S-trap "were not identical" and therefore could have interfered with results [5]. Whilst Bokor's findings were in relation to solids' transfer, (referring to potential contamination routes in building drainage and ventilation systems), Jack et al. suggest that the assumptions on "provision or 
overprovision" of ventilation will suffice in being able to counteract any adverse pressure effects in the system. They revealed that there are many cases where ventilation pipework only gives a minimal advantage when considering the pressure relief location being remote from where it is required. Jack et al. examined high rise building drainage design [37]. Swaffield was co-author on the Jack et al.'s papers [37] [38]. This is a significant area of research in which Swaffield had been involved in and has published a book relating to this subject area entitled Transient Airflow in Building Drainage [25]. This area of research provides an important context to their studies.

\subsection{Recommendations for Further Work}

Wakelin stated that variation existed between the maternity pads being used in the tests and highlighted that future research programmes must investigate the provision of simulated human faeces [5]. Wakelin also recommended that flow mechanics in pipelines should be investigated further due to a limited amount of knowledge in this area relating to drainage systems. Wakelin further recommended that investigation should try and determine the effect of installation errors.

\section{SD Bokor}

\subsection{Introduction}

As with Wakelin's study, Bokor's study [6] was conducted under the DHSS research requirements and aimed to address problems in hospital drainage systems. The test-rig used was an adapted version of that used by Wakelin [5]. Bokor also used the drainage from a live site and chose the toilets situated close to the Nurses' Education Department of Greenwich District Hospital which had clear drainage pipes fitted to accommodate the study [6]. The toilet facilities were split into male and female and were open to staff, the public and patients. The study also used other live sites for observational purposes. Reference by Bokor [6] on Wakelin's [5] original work is made in Section 2.5. One of the components of Bokor's work was to simulate human faeces.

\subsection{Human Faeces Simulation}

When considering the loading to be used in the tests, Bokor [6] made reference to the maternity pads used by Swaffield [16] and Wakelin [5]. Wakelin made recommendations for simulated human faeces to be developed for testing [5]. Bokor ruled out the use of actual human faeces in the experiments because of the hazard that this could be to public health in procuring, transporting and eventual disposal and storage which were also seen as problems in that they were "insoluble" [6]. Gormley also made reference to the use of human faeces in experimental work as being "unacceptable for many reasons" with specific reasons not being detailed [39]. An account of typical information on solids' dimensions is provided by Gormley [39] and matches the information provided by Kira [40] citing information from an American study which reported that a healthy adult 
produces a stool (solid) of between 100 and $200 \mathrm{~g}_{\text {wet }}$ (where gwet refers to wet mass) with a length range of $100 \mathrm{~mm}$ to $205 \mathrm{~mm}$ and a diameter of $15 \mathrm{~mm}$ to 40 $\mathrm{mm}$. Bokor [6] provided another two references which agree with the findings by Kira [40], in relation to mass output. These other references refer specifically to faeces output over 24-hours for adults on mixed diets as being on average 150 $\mathrm{g}_{\text {wet }}$. Wyman et al. provided a study that included ten males and ten females and, on average, females produced $125.80 \mathrm{~g}_{\text {wet }}$ per day and males produced $131.10 \mathrm{~g}_{\text {wet }}$ per day [41]. The Wyman et al. study gave the largest stool in terms of mass as being $250 \mathrm{~g}_{\text {wet }}$ [41]. Other studies have come up with lower average daily faeces outputs, for example, Wozasek and Steigman found average daily faeces outputs to be $115 \mathrm{~g}_{\text {wet }}$ per person based on a group of 30 people on "unspecified diets" [42]. As there is no universal agreement as to the average stool size, this adds to the challenge of research in this area.

\subsection{Faeces and Substitute Model Solids}

\section{Properties of faeces}

Bokor examined human faeces simulation and identified the failure to properly simulate human faeces as having delayed drainage research [6]. Bokor presented comprehensive information relating to the properties of human faeces, for example, the use of cellulose [6]. Bokor [6] cited Boerner and Sunderman [43], Albritton [44] and Gradwohl [45] as agreeing that cellulose is found in faeces as indigestible food residues; Goldbith and Wick provide a list of other elements that can be found in human faeces including skatole, methane, hydrogen, fats, vitamins, minerals, ammonia and carbon dioxide [46]. Bokor reported that faeces can contain approximately $67 \%$ water by mass and non-pathogenic bacteria of approximately $33 \%$ by dry mass [6]. According to Watson, faeces can contain $40 \%$ fat and above depending on the diet of the individual [47] and, even at this level of fat content in faeces, this is not considered as an abnormal loss of fat. According to Torondel, faeces can contain 30\% fat [48]. Bokor provides the specific gravity of faeces in the range of 1.0 to 1.05 . Bokor states that solids having a specific gravity greater than 1.05 may be considered in the study because "no evidence to support this being an upper limit was available" [6]. Wyman et al. provided information on specific gravity and provides the maximum recorded specific gravities for faeces as 1.086 and 1.24 for females and males respectively [41]. It should be noted the average recorded specific gravities for faeces were 0.96 and 0.92 for females and males respectively. Similarly on the issue of stool size, there is limited agreement on specific gravities; therefore this presents a gap in the research area.

\section{Simulated solids}

Bokor recommended that any simulated solid would require durability due to friction in order to save "both time and material" and the problems encountered when shaping the simulated solids [6]. Bokor also recommended that an essential component of any simulated solid is that the solid be capable of being used continually whilst still being flexible [6]. In developing a simulated solid (re- 
ferred to as a "model solid" by Bokor), the following materials were trialled [6]:

1) Fakazell: this is a product developed by Knoblauch to test WC pans/bowls in terms of their ability to clear the bowl of solids [49]. It is possible that Bokor became aware of the existence of Fakazell through the Drainage and Water Supply for Building Conference that took place at Brunel University in June 1980 which was organised by the Drainage Research Group at Brunel. At the aforementioned conference, Professor Hans-Joachim Knoblauch presented a paper which outlined the manufacture of Fakazell which was described in the paper by Knoblauch as "a paste like faecal matter substitute" [49]. The ingredients were given as $20 \%$ solids which are primarily cellulose and $80 \%$ water. There is no more specific detail available on the cellulose aspect of the mix design. Fakazell was manufactured in two specific gravity ranges-1.03 - 1.05 referred to as Fakazell 105 and 0.95 0.97 referred to as Fakazell 95. Bokor wrote at length about each material trialled and refers to Fakazell as the "most obvious candidate of the available material" as simulated faeces because of the characteristics displayed by Fakazell including flexibility, consistency and appearance [6]. Bokor acquired Fakazell solids and used them in the laboratory test-rig and found that the Fakazell solids regularly bypassed one another during multiple flush testing scenarios. Bokor ruled Fakazell out as a simulated solid because the by-passing witnessed as by-passing of actual solids was not witnessed during the field work undertaken.

2) Flour putty was also tested by Bokor in conjunction with a variety of filler material including papier-mâché, sawdust and polystyrene. Bokor ruled out these mix designs as the simulated solid surface caused the solid to adhere to the wall of the pipe and did not appear to match the observed live waste loadings.

3) Polyvinyl alcohol sponge was trialled. The retention of air in the solid resulted in unpredictability in the testing including the measuring of the specific gravity of each simulated solid.

4) Polyvinyl alcohol powder was also used in mix designs and was discounted for use in Bokor's testing regime because of the tendency for these solids to be "extremely elastic" which led to a considerable amount of flush failures in terms of evacuation of the WC pan.

5) Potter's clay was also tested but was eliminated as a possible simulated solid contender because the specific gravity of each mix was greater than 2.0.

6) Bokor also reported on a number of sanitary protection products that were tested.

7) Bokor [6] described the scale of an investigation to find the "norm" in terms of a simulated solid as being "immense" and concluded that a simulated solid may not be practical and opted to use maternity pads as loading to simulate solids used by Wakelin [5] and Swaffield [16]. Bokor made reference to the National Bureau of Standards' (NBS) approach which was described as using plastic cylinders that could have varied specific gravities [6]. The cylinders were reported to vary in diameter from $10 \mathrm{~mm}$ to $38 \mathrm{~mm}$ and in length from $38 \mathrm{~mm}$ to $80 \mathrm{~mm}$. Use of the NBS solid, as a substitute for human faeces, features in a number of rig-based testing regimes including McDougall and Swaffield [50], 
Davies et al. [51], Littlewood [29], Gormley [39], Gormley and Campbell [52], McDougall and Wakelin [53] and Memon et al. [54].

\subsection{Steep Gradients}

Bokor [6] reported research carried out by Swaffield and Marriott [17] which examined steep gradients between $30^{\circ}$ and $90^{\circ}$ to the horizontal. Bokor [6] stated that this study "put paid to the common belief that, due to water velocity tending to greatly exceed solid velocity, solids could become stranded" when transported along pipes laid at steep gradients. A CIRIA report by Ackers et al. [55] entitled Design of sewers to control sediment problems, which makes no reference to the work of Swaffield and Marriott [17] is cited in BS EN 752:2008 [56] as evidence that steep gradients do not cause deposition of solids. The report by Ackers et al. (under further work) makes reference to this being a "completely new methodology, unproven in practice" [55]. To this day, this remains the case.

\subsection{Standard of Quality}

Bokor pointed out that, from personal experience observing trades persons installing pipework on site, sufficient attention to detail was not taken in terms of jointing pipework [6]. Bokor concluded from the laboratory work undertaken that poor quality control, in terms of jointing pipes, directly resulted in solids being deposited prematurely [6]. This was further supported by Littlewood [29] who concluded that

"the movement of the solid was found to be very sensitive to joints and imperfections in the pipe. A displacement of less than $0.5 \mathrm{~mm}$ was found to affect the solid transport, particularly when the solid was moving with velocity of less than $0.25 \mathrm{~m} / \mathrm{s}$ ".

Bokor went on to discuss the significance of the pipe being positioned at the correct gradient throughout [6]. Bokor found that when considering a flush to remove deposits, the efficiency of a flush "was inversely related to the size of the original load" [6]. It was also found through the live testing that, in normal circumstances, faecal solids being transported in drainage do not pass each other; thereby, contesting the use of Fakazell.

\subsection{Recommendations for Further Work}

Bokor made a number of recommendations for further work which focused on WC design, including the discharge geometry from WCs, along with the impact of pipe fittings and varying pipe diameters [6]. Whilst the varying circular pipe diameters have been investigated by Littlewood [29], the area of non-circular pipes is an aspect which has not been definitively researched.

\section{Lillywhite}

\subsection{Introduction}

Lillywhite and Webster made significant contributions to the area of determin- 
ing blockage occurrences in sewers [7]. Lillywhite and Webster looked at the area of sewer blockages, whilst providing an historical account of research carried out to help understand solid transport [7]. McDougall and Swaffield [57] describe the work by Lillywhite and Webster [7] as one of the earliest systematic drain blockages' studies carried out in the UK. The historical account also provides information from the Sanitary Institution, London describing a solid transport test from a WC carried out using a series of $12.5 \mathrm{~mm}$ balls used in the 1890s. McDougall and Swaffield [57] made the connection between the type of test carried out by the Sanitary Institution, London regarding the use of $12.5 \mathrm{~mm}$ balls as being similar to the standard tests carried out in the USA. Gauley and Koeller [33] (as described in Section 8) made changes to the media for testing of WCs and solid transport in sewers by trialling the use of soya paste.

Lillywhite et al. studied low water use washdown WCs [8]. This research involved rig-based testing at one of the sites. The early research on sewer blockages is given in Section 4.2 and the research involving rig-based testing is given in Section 4.3. Unless stated otherwise, the reference to sewer blockages in Section 4.2 refers to combined sewer systems.

\subsection{Sewer Blockages}

Sewer blockages can happen for a number of reasons. In 2007, it was reported by BBC News that a bra and a pair of knickers were allegedly responsible for blocking a $225 \mathrm{~mm}$ diameter sewer in Middleton Saint George, close to Darlington in Co. Durham, England [58]. A spokesperson said that "these sewers are not designed to carry bras and knickers". The underwear, coupled with heavy rain and a build-up of grease and fat, reportedly caused the blockage which led to the sewer bursting and approximately $10 \mathrm{~m}$ of road along the sewer trench collapsing. The repairs were estimated to cost $£ 15,000$. Sewer blockages have been a problem for many decades.

Lillywhite and Webster provided results of a site investigation which included two site based studies [7]. The first study, designed to identify blockage causes, looked at $100 \mathrm{~mm}$ and $150 \mathrm{~mm}$ diameter pipes which had been subject to a series of blockages over a minimum duration of two years. The study used Closed Circuit Television (CCTV) which identified a total of 70 faults in the sewers surveyed. The second study involved surveying 194 no. $100 \mathrm{~mm}$ diameter clayware "normal drains" subject to random blockages. This used a gradient meter connected to an adapted level to calculate the mean gradient between chambers.

The main finding from the first study was that defective pipe joints were the most common cause of blockage, accounting for 21 (or 30\%) out of the total 70 identified faults. One of the main conclusions from the study was that good installation of drains is the most important factor in reducing sewer blockages. Deposits in the line were also identified as being a considerable factor in blockages, accounting for 16 (or 22.86\%) out of the total 70 identified faults.

The second study focused mainly on sewer gradients and concluded that the incidence of blockages did not seem to be "seriously" influenced by the sewer 
gradient. However, this point has been disputed by other researchers including Fenner et al. [59] and Rodríguez et al. [60] who reported that flat gradients were one of the major causes of sewer blockages. It could be argued, however, that the methodology adopted by Lillywhite and Webster [7], in terms of intrusive investigation coupled with onsite gradient confirmation, may be more in-depth than some of the desk top statistical analysis carried out by others. Lillywhite and Webster support their argument in relation to drainage by making reference to a $100 \mathrm{~mm}$ diameter clayware sewer which was part of the second study and was laid at a gradient of approximately $1 / 1200$ which had no history of blockages and was working sufficiently well [7]. Since the work by Lillywhite and Webster, other significant contributions have been made [7].

Park and Lee refer to joint type selection as the main cause of joint related problems [61], for example, the use of non-flexible joints in conditions where there may be ground movement. Fenner described the use of flexible joints and the use of synthetic rubber rings and pointed out that there is a likelihood that these joints could perish in a given environment causing failure of the joint [62]. Arthur et al. report that sewer blockages occurred in pipes of less than $225 \mathrm{~mm}$ diameter [63]. This information was based on data relating to a catchment in southern England of $30.8 \mathrm{~km}$, serving a town with a population of approximately 10,000 people. The majority of the pipes $(86 \%)$ were $150 \mathrm{~mm}$ to $300 \mathrm{~mm}$ diameter. The majority of the pipe network was a combined system at approximately $60 \%$ capacity. Table 1 contains a summary of factors presented by Arthur et al. [63] who indicated increased blockage likelihood. Beattie and Brownbill [64] concur with Arthur et al. [63] and suggest that $100 \mathrm{~mm}$ to $150 \mathrm{~mm}$ diameter pipes are more susceptible to blockages and suggested that these smaller diameter pipes could have up to three times more blockage occurrences than larger diameter sewers.

Purcell stated that pipe sizes smaller than $150 \mathrm{~mm}$ in diameter are "usually not practical due to the risk of blockage" and also notes this point in foul sewer design examples when considering the adequacy of pipe diameters [65]. Marlow et al. reported that sewer diameter is one of the most significant factors in relation to sewer blockages [66]. This claim is based on analysis from two water companies in Australia. The analysis included approximately $13,000 \mathrm{~km}$ of sewer network with pipework of $300 \mathrm{~mm}$ diameter and under and concluded that $100 \mathrm{~mm}$ diameter pipes were the cause of the majority of blockages and went on to report that increased diameter pipes reduced the probability of blockages. Marlow et al. [66] present data on blockage type for each of the companies as presented in Table 2 which clearly shows that fats, oils and grease (FOG) are major causes of blockages. Fenner et al. [59] and Marlow et al. [66] agree on a number of sewer blockage problems. The problems include material selection in terms of sewer pipe, increased age of the sewer (with pipeline age increase resulting in an increase in probability of blockage), tree roots, particularly in smaller diameter sewers, which can enter the pipeline because of defective pipe joints or defective connections made to pipelines, and pipelines laid at shallow depths (usually less 
Table 1. Factors that may indicate increased blockage likelihood [63].

\begin{tabular}{lcc}
\hline \multicolumn{1}{c}{ Factor } & $\begin{array}{c}\text { Apparent } \\
\text { increased } \\
\text { likelihood } \%\end{array}$ & $\begin{array}{c}\text { Is the result } \\
\text { statistically } \\
\text { significant? }\end{array}$ \\
\hline Combined pipes are more likely than foul pipes to block & 146 & Yes \\
Pipes that surcharge during a 5-year return period design storm & 44 & No \\
Pipes that flood during a 5-year return period design storm & 839 & Yes \\
Pipes that convey flows influenced by a backwater effect & 55 & No \\
Proximity to flow confluence: pipes just upstream of a junction & 38 & No \\
$\begin{array}{l}\text { Pipes that fail to achieve peak flow velocity of 1 m/s during a } \\
\text { 2-year return period event }\end{array}$ & 81 & Yes \\
Pipes laid at a gradient less than 1 pipe diameter & 102 & Yes \\
Pipes with large direct inputs & 167 & Yes \\
Pipe size-the majority of blocked pipes were $\leq 225 \mathrm{~mm}$ & 521 & n/a \\
\hline
\end{tabular}

Table 2. Report of blockage numbers by type [66].

\begin{tabular}{ccccc}
\hline \multirow{2}{*}{ Blockage type } & \multicolumn{2}{c}{ Company A } & \multicolumn{2}{c}{ Company B $^{\mathrm{a}}$} \\
\cline { 2 - 5 } & Total blockages & Percentage & Total blockages & Percentage \\
\hline Damaged pipe & 227 & 3.1 & 38 & 0.6 \\
Foreign object & no data & no data & 265 & 3.9 \\
FOG & 1552 & 20.8 & 517 & 7.5 \\
Sediment & no data & no data & 248 & 3.6 \\
Tree roots & 5001 & 67.2 & 4981 & 72.4 \\
Unknown/other & 664 & 8.9 & 830 & 12.1 \\
\hline
\end{tabular}

${ }^{a}$ represents Company B blockage data from June 2004 to 2008. Between 1999 and June 2004, no cause was logged for the 7922 blockages experienced. ${ }^{b}$ includes FOG-related tree-root blockages.

than $1.0 \mathrm{~m}$ ). Littlewood reports on causes of blockages and provides information that includes design issues, solids' deposition and workmanship problems [29].

Marlow et al. [66] provide the blockage rate for both Australian water companies, as shown in Table 3, and it can be seen that the blockage rate varied significantly for the $100 \mathrm{~mm}$ nominal bore pipe; with Company A and Company B reporting 29.59 blockages $/ 100 \mathrm{~km} /$ year and 65.20 blockages/100 km/year however the researchers could not identify the reason for the differential.

On the subject of blockage rates, Arthur et al. (2008) [63] provide a rate of 1.14 complaints/km/year (114 complaints/100 km/year) for the case study completed in England and reports 2.48 complaints $/ \mathrm{km} /$ year (248 complaints $/ 100$ $\mathrm{km}$ /year) from the US EPA; however, the word complaint is not defined in terms of a complaint made relating to an actual blockage. UK blockage rates for public and private sewers vary between $0.5 / \mathrm{km} /$ year and $1.0 / \mathrm{km} /$ year (Water Branch, 2011) [67]. These UK and USA figures are comparable with the Australian study carried out by Marlow et al. [66]. 
Table 3. Blockage rate by sewer diameter [66].

\begin{tabular}{ccccc}
\hline \multirow{2}{*}{$\begin{array}{c}\text { Material } \\
\text { diameter } \\
\text { (nominal) }\end{array}$} & \multicolumn{2}{c}{ Company A } & \multicolumn{2}{c}{ Company B } \\
\cline { 2 - 5 } & Blockages (total) & $\begin{array}{c}\text { Blockage rate } \\
\text { (per 100 km/year) }\end{array}$ & Blockages (total) & $\begin{array}{c}\text { Blockage rate } \\
\text { (per 100 km/year) }\end{array}$ \\
\hline 100 & 235 & 29.59 & 50 & 65.20 \\
150 & 6,195 & 15.18 & 13,705 & 23.55 \\
225 & 1,015 & 7.12 & 772 & 11.83 \\
300 & 42 & 1.69 & - & - \\
\hline
\end{tabular}

Marlow et al. reported briefly on a significant trend between periods of drought, when water restrictions were implemented, and an increase in sewer blockages occurring approximately three months thereafter [66]. This may be linked to solids being deposited during the water restrictions. Marlow et al. found that there was a significant link between higher blockage rates and lower water use [66]. The Institution of Sanitary Engineers (ISE) [29] provides the following causes of blockages:

- Poor trap design.

- Very flat gradients.

- Excessively large pipes.

- Liberal use of bends, where strictly not necessary.

- Poor inlet design in manholes.

- Manholes containing building material.

- Displaced interceptor rodding eye stoppers.

- Workers laying pipes poorly, particularly with flat gradients.

- Bad jointing of pipes.

- Defective construction of manholes.

- Use of straight pipes for curves.

- The entry of tree roots into pipes.

Littlewood highlighted that one of the possible solutions given by the ISE's 1954 report was to use smaller pipe diameters and that $75 \mathrm{~mm}$ diameter pipes could be considered as an alternative to $100 \mathrm{~mm}$ diameter pipes; this was to increase self-cleansing velocities with the condition that "first-class workmanship" be employed for the pipelaying operations [29]. Littlewood went on to point out that the ISE report estimated that " $60 \%$ of blockages were attributable to misuse" and it would not be feasible to use $75 \mathrm{~mm}$ diameter pipes for "WC pans with outgoes of larger size" [29].

The study by Fenner et al. was based on $2000 \mathrm{~km}$ of sewer network (from 12 separate catchments) and concluded that "shallow slack or moderate" pipe gradients coupled with long pipeline lengths and small pipe diameters increase the probability of sewer blockages [59]. Arthur et al. made reference to the significance of low-flow volumes and flow depths in terms of blockage occurrences and also cite slack gradients, low self-cleansing velocities, large solids, and pipes under $225 \mathrm{~mm}$ diameter as increasing blockage probability and, suggests that com- 
binations of factors require further investigation [63].

Rodríguez et al. investigated a sample data set which included more than 248,000 customer complaints about sewer blockage in Bogota, Colombia (covering $7678 \mathrm{~km}$ of pipeline) and suggested that the majority of blockages occurred in pipes of between $0.2 \mathrm{~m}$ and $0.4 \mathrm{~m}$ diameter which were laid at "mild slopes given as between $1 / 1000$ and 1/100" [60]. It appears from that data that pipe diameters of $0.15 \mathrm{~m}$ to $0.9 \mathrm{~m}$ were considered in the investigation. Rodríguez et al. reference in excess of fifty works that mainly looked at sewer blockages and report that research has shown that sediment deposition is related to the sewer location and its "physical characteristics" [60]. However, they go on to state that "nevertheless, there is no consensus on which physical properties can be considered as influential factors". Furthermore, Rodríguez et al. also acknowledged that, while there may be several factors, pipe diameter and pipe age remain what the majority of previous researchers have concluded as being the "significant factors" [60]. The study concluded from the Bogota blockage data that pipe gradient, pipe diameter and pipe length are the significant factors that influence blockages occurring. Table 4 summarises blockage problems identified from the authors included in Section 4.2.

Lack of hydraulic capacity has also been identified as a contributory factor in sewers being damaged through surcharge resulting in blockages. Researchers such as Fenner [68] and Arthur et al. [63] have suggested that a combination of factors, such as shallow pipe gradients, long pipeline lengths and small pipe diameters, increase the probability of sewer blockages. Small diameter pipes have been identified by four out of the seven researchers as a factor that can lead to or increase the probability of pipe blockages. Davies et al. state that "larger sewers are laid with more care and precision by more experienced personnel who are subject to a greater level of supervision" [69]. This may be a significant point in relation to the reason for small diameter pipes being reported to have increased blockage occurrences. The study by Davies et al. examined factors that can result in collapsed mechanisms with a number of these factors also identified by other researchers in relation to blockage factors [69]. For example, Davies et al. reported the factors influencing "the likelihood of a sewer failing structurally" including the amount of traffic passing over the locations where pipes were laid [69].

\subsection{Low Water Use Wash-Down WCs}

Lillywhite et al. investigated WC performance at reduced flush volumes [8]. The study began with laboratory experiments on WCs with reduced volumes and then identified ten live sites. These included council houses, a BRE workshop toilet and office toilets at various locations, including a BRE office facility referred to as Sites $\mathrm{J}$ and $\mathrm{O}$ which used an experimental glass drain test-rig. The glass drain test-rig, for example, was used to temporarily replace the existing pipework at Site $\mathrm{O}$ which was located in a basement car park at the underside of ceiling level. The existing $100 \mathrm{~mm}$ diameter pipe from Site O had $22.0 \mathrm{~m}$ of the 
Table 4. Pipe blockage factor problem identified or cited by author.

\begin{tabular}{|c|c|c|c|c|c|c|c|}
\hline \multirow{2}{*}{$\begin{array}{c}\text { Factors identified that } \\
\text { can lead to pipe } \\
\text { blockages. }\end{array}$} & \multicolumn{7}{|c|}{ Factor identified or cited by author } \\
\hline & $\begin{array}{l}\text { Arthur } \\
(2008)\end{array}$ & $\begin{array}{l}\text { Davies } \\
\text { (2001) }\end{array}$ & $\begin{array}{l}\text { Fenner } \\
(2000)\end{array}$ & $\begin{array}{c}\text { Lillywhite } \\
\text { (1979) }\end{array}$ & $\begin{array}{l}\text { Littlewood } \\
(2000)\end{array}$ & $\begin{array}{l}\text { Marlow } \\
\text { (2011) }\end{array}$ & $\begin{array}{c}\text { Rodriguez } \\
\text { (2012) }\end{array}$ \\
\hline Age of sewer & & $\mathrm{X}$ & & & & & $\mathrm{X}$ \\
\hline Depth of cover & & $\mathrm{X}$ & $\mathrm{X}$ & & & $\mathrm{X}$ & $\mathrm{X}$ \\
\hline Fats, oils and grease & & & $\mathrm{X}$ & & $\mathrm{X}$ & $\mathrm{X}$ & $\mathrm{X}$ \\
\hline Flat gradients & $\mathrm{X}$ & & $\mathrm{X}$ & & & & $\mathrm{X}$ \\
\hline Joint/material type & & $\mathrm{X}$ & & $\mathrm{X}$ & & $\mathrm{X}$ & \\
\hline Junctions & $\mathrm{X}$ & & & $\mathrm{X}$ & $\mathrm{X}$ & & \\
\hline Ground conditions & & $\mathrm{X}$ & $\mathrm{X}$ & & & $\mathrm{X}$ & \\
\hline Gross solids/misuse & $\mathrm{X}$ & & & $\mathrm{X}$ & $\mathrm{X}$ & $\mathrm{X}$ & $\mathrm{X}$ \\
\hline Intermittent flow & $\mathrm{X}$ & & & & $\mathrm{X}$ & $\mathrm{X}$ & \\
\hline Length of sewer & $\mathrm{X}$ & & $\mathrm{X}$ & & & & $\mathrm{X}$ \\
\hline Self-cleansing velocity & $\mathrm{X}$ & & & & $\mathrm{X}$ & & \\
\hline Solid deposition & $\mathrm{X}$ & & $\mathrm{X}$ & & $\mathrm{X}$ & & \\
\hline Small diameter & $\mathrm{X}$ & & $\mathrm{X}$ & & & $\mathrm{X}$ & $\mathrm{X}$ \\
\hline Tree roots & & $\mathrm{X}$ & $\mathrm{X}$ & $\mathrm{X}$ & $\mathrm{X}$ & $\mathrm{X}$ & $\mathrm{X}$ \\
\hline Quality (construction) & & & & $\mathrm{X}$ & $\mathrm{X}$ & $\mathrm{X}$ & $\mathrm{X}$ \\
\hline
\end{tabular}

Notes: 1) An X below the author corresponds to a problem identified that can lead to pipe blockages. This means that the author has explicitly written about the factor. 2) The information in the factor identified that can lead to pipe blockages is tabulated based on two or more researchers identifying or citing the same problem. 3) Inadequacies or failures in design have featured among designers as a problem that can lead to an increased probability of blockages. Quality (construction) is used interchangeably with workmanship.

total $25.0 \mathrm{~m}$ long pipe replaced with a test rig that allowed observations to be made and water depths to be taken. The Site O test rig, which served two WCs, allowed gradient changes to be made. Both WCs had their flush volumes reduced to 5.25 litres and the WC use was reported to be "very low" with no weekend use. The flush volumes were reduced for experimental purposes to 3.0 litres. Site $\mathrm{O}$ was the only site where a blockage was established. The blockage occurred at a gradient of $1 / 120$ as a result of multiple stoppages whilst using a flush volume of 3.0 litres.

The study by Lillywhite et al. included the use of CCTV to check the existing drains before and after the period of reduced flushing volumes [8]. A number of findings from the study were reported as follows:

- There are existing WCs that could be used for flushes of 6 litres without loss in toilet function to clear the bowl or to transfer solids in the drains.

- Solid transfer in sewers could be adversely affected by flush volumes of less than 4 litres. For flush volumes of less than 3 litres, the likelihood of a drain blockage could be increased where there are longer pipe lengths or shallow gradients.

- Some existing WCs could be used for flushes of 5 litres, without loss in standards of cleaning, but most would require some modifications for this size 
flush.

- It is possible to produce a WC which will give desired function at 5 litres through revised design of the cistern/WC.

- Restrictions on sewer length and gradient may need to be imposed when catering for isolated WCs.

- Cisterns with maximum 7.5 litre volumes are technically available and do not pose a problem to the sewer system or the WC user.

The findings of the study by Lillywhite et al. [8] are significant in terms of offering assurances in terms of the Model Water byelaws which came into effect in 1993. These revised the maximum nominal flush from 9.5 litres to 7.5 litres which fits into the water conservation agenda through ongoing reduction cistern volumes.

\subsection{Recommendations for Further Work}

Lillywhite and Webster recommended that further research be carried out in the area of sewer blockages in order to generate informed design guidance for sizing sewers [7].

\section{Butler (Ackers, Ashley, Brown, Davies and Jefferies)}

\subsection{Introduction}

There is a myriad of researchers involved in collaborative research in the area of solids' transfer. One example is Butler who has been involved in several collaborative studies; these studies have included working with Ackers, Ashley, Brown, Davies and Jefferies-some of which will be discussed in this section. Examples of studies that are not specifically discussed in this section are Butler (as doctoral supervisor and part of the work by Babaeyan-Koopaei et al. [70]) who carried out modelling of gross solids' transport in sewers and looked at continuous steady flow.

Butler's $\mathrm{PhD}$ was entitled “Modelling the variation of domestic dry weather flow in sewer networks" [10]. Butler and Graham published a paper on the modelling of unsteady domestic dry weather flow in sewers and found intermittent flow to be complicated due to the number of discharges including WC and white goods [11]. Butler and Graham looked at intermittent flow and dry weather flow and suggested that both conditions increased sediment deposition [13]. Butler also was supervisor on the doctoral study carried out by Littlewood [29] (discussed in Section 1.7) and also contains collaborations between Butler and Littlewood. Butler was a co-author in Ashley et al. [71] in a paper entitled Making Asset Decisions for Wastewater Systems That Include Sustainability. Butler also co-authored a paper by Ashley et al. [72] entitled Sustainable decision making for the UK water industry. This paper explained SWARD as a framework to support decisions and demonstrates decision-making through the use of a case study. The case study looks at the management of domestic sanitary waste and refers to sanitary waste being flushed through the WC as being "habitual" in the 
UK. The decision-making process used criteria which included social, economic and technical considerations. It also involved a workshop and provided six possible options to the problem of pollution at CSOs from sanitary domestic waste. The top three options from the analysis were storm water source control retrofitting; the "think before you flush campaign"; and sewer rehabilitation. The bottom three options were the installation of $6 \mathrm{~mm}$ screens, restricted WCs and flow storage. When referring to the use of screens at CSOs, Ashley et al. state that "the requirement for screening is a direct result of the almost ubiquitous disposal of gross solids by WC" [72]. Butler was involved in a number of WC usage studies that provided important data for rig-based testing [10].

\subsection{Domestic Appliance Discharge}

Butler completed a "small scale study of wastewater discharges from domestic appliances" [9]. This was based on a 1987 survey involving friends, staff and students at South Bank Polytechnic (including their families) involving a total of 28 households. Butler reports that the sample in question is biased "as expected" towards managerial groups [9]. The results from the appliance usage are provided in Table 5.

Table 5 shows that there was a total of 165 shower uses compared to 124 bath uses during the period, giving approximately 1.91 shower uses for every bath use. The Energy Saving Trust reports that people use the shower on average 4.4 times per week with average bath use of 1.3 times per week, giving approximately 3.39 shower uses for every bath use [73].

The difference in the results between both studies may be influenced by at least two factors, including the time difference between both studies, i.e. Butler (1991) [9] (as cited by the Journal of the Institution of Water and Environmental Management (1991) [74]) and the Energy Saving Trust (2013) [73] -approximately 26 years later. During this time, changes have taken place in the way that water is used. Similarly, there is a vastly different sample size, with Butler having a sample of 28 households and the Energy Trust having 86,000 households.

Table 5. Appliance usage throughout the week [9].

\begin{tabular}{|c|c|c|c|c|c|c|c|c|}
\hline \multirow{2}{*}{ Appliance } & Sun & Mon & Tue & Wed & Thu & Fri & Sat & \multirow{2}{*}{ Total No. } \\
\hline & \multicolumn{7}{|c|}{$\%$ of the week } & \\
\hline WC & 14 & 16 & 14 & 14 & 14 & 14 & 14 & 1956 \\
\hline Basin (E) & 11 & 17 & 16 & 15 & 10 & 17 & 14 & 345 \\
\hline $\operatorname{Basin}(\mathrm{R})$ & 14 & 17 & 14 & 14 & 15 & 13 & 13 & 1463 \\
\hline Sink $(E)$ & 15 & 22 & 11 & 12 & 14 & 11 & 15 & 431 \\
\hline $\operatorname{Basin}(\mathrm{R})$ & 12 & 27 & 14 & 11 & 13 & 12 & 11 & 625 \\
\hline Bath (E) & 19 & 15 & 16 & 8 & 12 & 15 & 15 & 124 \\
\hline Shower & 13 & 16 & 14 & 14 & 18 & 15 & 10 & 165 \\
\hline $\begin{array}{l}\text { Washing } \\
\text { machine }\end{array}$ & 16 & 22 & 6 & 7 & 16 & 12 & 21 & 86 \\
\hline
\end{tabular}

Notes: $\mathrm{R}=$ running to waste; $\mathrm{E}=$ Emptying. 
It should be noted that Butler compared the results obtained with four other surveys and concluded that this small scale study was reasonably reliable and that useful information can be obtained from small scale surveys.

Butler reported on "the influence of dwelling occupancy and day of the week on domestic appliance wastewater discharges" and also involved 28 households with average occupancy of 2.71 [12]. The domestic appliances included in the study were WC, basin, sink, bath, shower and washing machine. The study showed a distinct diurnal pattern peaking in both morning and evening for domestic appliance use. The pattern of use for weekends differed from weekdays with the morning peak occurring at $07.30-08.30 \mathrm{am}$, earlier than the weekend morning peaks. The study revealed that the wash basin was the most used appliance followed by the WC with the kitchen sink being the third most used appliance.

\subsection{Domestic WC Usage Patterns}

Friedler et al. carried out a 7-day diary study of WC usage in 137 households in Southern England [75]. The data that had to be completed in the diary included the type of flush and time of flush, total amount of toilet paper sheets used and other items disposed of through the WC. The research presented as $A$ study of WC Derived Sewer Solids and described these solids as sanitary refuse, contraceptives, bathroom litter, toilet paper and faecal stools. The record of solids flushed (excluding faeces and toilet paper) is shown in Table 6.

Friedler et al. reported that "surprisingly, no sanitary towels were reported to be flushed" and went on to explain that, at the time of reporting, the amount of sanitary towels used in the UK was twice that of tampons [75]. From Table 6, it can be seen that only one condom was reported to be flushed during the study.

Littlewood [29] reports that in the Friedler et al. [75] study, participants were generally representative of the population in terms of sex and age; however, "but since the participants were recruited via Imperial College, London and Water Research Council (WRc), were probably not representative in terms of education and environmental awareness". Littlewood further explained that either environmental awareness or matters relating to intimacy may be the reason that the study reported only one condom and no sanitary towels being flushed during the reporting period [29]. Parker and Wilby [76], when referring to Butler's study [12] (see Section 5.2), makes the point that approximately $50 \%$ of the participants were from a managerial or professional background which is substantially higher than the national UK average of $15 \%$ and states that "this is a common limitation of household demand studies as datasets tend to be biased towards better educated and more water conscious socio-economic groups". It should be pointed out that Butler's study [12] was not simply a "household demand" study, as pointed out by Littlewood [29], the study required providing information of an "intimate nature". Laak et al. [77] and Feachem [78] (both cited in Friedler et al. [75]) provided information relating to faecal defecation, reporting that North Americans and Europeans excrete on average $100-130 \mathrm{~g}_{\text {wet }} /$ capita/day of faeces 
Table 6. Solid refuse flushed by the WC [75].

\begin{tabular}{|c|c|c|c|c|c|c|c|c|c|}
\hline \multirow{2}{*}{ Refuse } & \multicolumn{2}{|c|}{ Occurrences } & \multicolumn{2}{|l|}{ House } & \multirow{2}{*}{ Refuse } & \multicolumn{2}{|c|}{ Occurrences } & \multicolumn{2}{|l|}{ House } \\
\hline & Count & {$[\%]$} & Count & [\%] & & Count & {$[\%]$} & Count & [\%] \\
\hline Tampon & 78 & 22.9 & 15 & 10.9 & Blotted lipstick & 5 & 1.5 & 2 & 1.5 \\
\hline Wet wipes & 49 & 14.4 & 8 & 5.8 & $\begin{array}{l}\text { Toe/finger } \\
\text { nails }\end{array}$ & 4 & 1.2 & 3 & 2.2 \\
\hline Tissue paper & 40 & 11.8 & 13 & 9.5 & Facial tissue & 4 & 1.2 & 2 & 1.5 \\
\hline Cat faeces & 24 & 7.1 & 2 & 1.5 & Makeup & 3 & 0.9 & 3 & 2.2 \\
\hline Dental floss & 15 & 4.4 & 5 & 3.6 & Chewing gum & 3 & 0.9 & 1 & 0.7 \\
\hline $\begin{array}{l}\text { Other non } \\
\text { specified }\end{array}$ & 13 & 3.8 & 7 & 5.1 & Cigarette & 2 & 0.6 & 2 & 1.5 \\
\hline Panty liner & 13 & 3.8 & 4 & 2.9 & Spider & 2 & 0.6 & 2 & 1.5 \\
\hline Paper towel & 13 & 3.8 & 3 & 2.2 & Sheep tick & 2 & 0.6 & 1 & 0.7 \\
\hline Hair & 12 & 3.5 & 7 & 5.1 & Bandage & 1 & 0.3 & 1 & 0.7 \\
\hline $\begin{array}{l}\text { Tampon } \\
\text { applicator }\end{array}$ & 12 & 3.5 & 4 & 2.9 & Condom & 1 & 0.3 & 1 & 0.7 \\
\hline Food & 10 & 2.9 & 9 & 6.6 & J-cloth & 1 & 0.3 & 1 & 0.7 \\
\hline Cotton wool & 10 & 2.9 & 4 & 2.9 & $\begin{array}{l}\text { Medicated } \\
\text { cream }\end{array}$ & 1 & 0.3 & 1 & 0.7 \\
\hline Cotton bud & 8 & 2.4 & 3 & 2.2 & Pot soil & 1 & 0.3 & 1 & 0.7 \\
\hline Leaves & 7 & 2.1 & 2 & 1.5 & Soap bar & 1 & 0.3 & 1 & 0.7 \\
\hline $\begin{array}{c}\text { Vomit } \\
\text { (human/animal) }\end{array}$ & 5 & 1.5 & 3 & 2.2 & & & & & \\
\hline
\end{tabular}

and that this defecation occurs on average once per person per day which closely matches the findings of Friedler et al. [79] in terms of average defecation occurrences, $g_{\text {wet }}$ refers to wet mass. The mass of faeces was not recorded/reported by the Friedler et al. [75] study. Other estimations on faeces $g_{\text {wet }} /$ capita/day are provided in Section 3.2. Friedler et al. also provided information on toilet paper use, giving the average UK toilet paper use as $19.4 \mathrm{~g} /$ person/day and found that, from the sample, the average toilet paper usage was 11.7 sheets/capita/day for weekdays and 14.2 sheets/capita/day at weekends for sanitary related flushes [75]. Friedler et al. also highlighted that these findings do not correspond to the UK toilet paper use as $19.4 \mathrm{~g} /$ person/day, based on an average sheet weighing $0.55 \mathrm{~g}$, and also reported that, for overall toilet paper use, females use $96 \%$ more toilet paper than males [75].

Friedler et al. [79] (which also included Butler and Brown) presented data that appears to be connected with the sample from Friedler et al. [75] and reported on domestic WC use patterns. The study found that each participating house had 1.44 WCs and that the flush rate was 3.98 flushes/capita/day for weekdays and 4.75 flushes/capita/day for weekends. It was noted that approximately $70 \%$ of participants were at work during weekdays. Friedler et al. found it as "quite surprising" that the faecal related flushes were 0.91 flushes/capita/day for weekdays and 1.15 flushes/capita/day for weekends [79]. This was put down to the 
possible preference for using the $\mathrm{WC}$ at home for faecal related flushes. The study also highlighted differences in female and male WC usage patterns showing greater use of WCs by females completing 4.2 flushes/capita/day and males completing 3.6 flushes/capita/day. Weekend data for females was 4.9 flushes/capita/day and 4.3 flushes/capita/day for males.

\subsection{Control of Sediment Problems}

Along with May, Butler was a co-author in the Ackers et al. study [55] which looked at the "design of sewers to control sediment problems". Sediment sources are described as large and fine faecal matter, paper and rags, material from sewer fabric decay, vegetable matter from food processing, and soil particles due to leaks. Ackers et al. did not specifically look at intermittent flow associated with "buildings drains and small sewers" [55]. Butler and Davies [80] have co-published a book on Urban Drainage which is now in the third edition. The chapter on foul sewers includes a section on small sewers which provides illustrations associated with work carried out by Littlewood [29]. The section on small sewers also includes reference to the Limited Solid Transport Distance (LSTD) which is referred to in Sections 6 and 7 herein. Butler also co-authored with Davies et al. [51] carrying out rig-based testing on a $15.0 \mathrm{~m}$ test-rig to investigate "Gross Solid Transport and Degradation". The degradation aspects were carried out on a variety of sanitary solids and faeces in a laboratory through the use of stirred magnetic beakers. The results showed that both toilet paper and faeces were readily degradable when subject to "long periods" of turbulence; however, panty liners, sanitary towels and condoms showed "little degradation". It was stated that "with limited data available it is still unknown to what degree" faeces degrade in field conditions [51], this point is also clearly made by Digman et al. [81] which included Butler as a co-author and looked at gross solids' loading in a combined sewage system.

The gross solid transport aspect included the use of seven types of NBS solid, ranging in density from 0.96 to 1.06 and ranging in diameter from $10 \mathrm{~mm}$ to 38 $\mathrm{mm}$. The study concluded that, based on the seven artificial solid sizes used, solid velocity did not "vary significantly" but stated that "with decreasing size, solids of the same density have been deposited at lower values of depth and velocity" Davies et al. [51]. Littlewood [29] reported contrasting results, stating that "solid size was probably the single most important factor affecting solid movement in intermittent flow, and that density has a limited effect" and makes reference to Davies et al. [51] looking at steady flow conditions.

\subsection{Recommendations for Further Work}

A number of recommendations for further work have been made from the studies that Butler has been involved in including:

- Investigation of the effect of steep gradients.

- Development of models to help understand sewer blockage formations. 
- Revised sewer sizing through further investigation of domestic peak discharges based on frequency of domestic appliance and WC use per capita.

The lack of available information relating to faeces degradation has also been suggested as a gap in two of the studies in which Butler has been involved. Further recommendations that Butler is associated with are included in Section 7 through collaborations with Littlewood.

Whilst not specifically looking at degradation of human faeces, the following researchers have carried out investigations that mainly related to bed erosion in combined sewers: Ahyerre et al. [82]; Arthur et al. [ 83]; Arthur et al. [84]; Arthur and Ashley [85]; Baban and Talinli [86]; Banasiak et al. [87]; Crabtree et al. [88]; Sakrabani et al. [89]; Seco et al. [90]; Tait et al. [91]; Verbanck et al. [92].

Stotz looked at the factors that affected the first flush in combined sewers and the removal of solids [93]. This study led to Stotz and Krauth using primary sludge from a Waste Water Treatment Plant (WWTP) in order to investigate the deposition of organic material in an $8.72 \mathrm{~m}$ channel which represented a combined sewer [94]. The study looked at the retention of the organic material in the open channel. One of the conclusions reached was that a mathematical solution to the problem was "somewhat difficult" because of the variability in solids' behaviour, particularly in relation to residence time. The study did not assess degradation and the approach taken in the use of primary sludge was innovative and avoided the problems associated with collecting human faeces. However, mean primary sludge physical characteristics do not mimic mean human faeces physical characteristics at the head of a catchment. To date, there is no research available that reports on the degradation of human faeces in a small catchment sewerage system.

\section{Swaffield}

\subsection{Introduction}

Swaffield has collaborated with many other researchers in the area of solids' transfer in drainage. For example, Swaffield and Marriot looked at the effect of reduced volume WC flushes on how solids were transported in above ground drainage [18]. Also, Swaffield and Bridge investigated the applicability of the Colebrook-White formula to represent frictional losses [19] [20]. Swaffield et al. looked at design, development and appraisal of a low volume flush toilet in Botswana [22].

- Swaffield and Galowin reported on multi-storey building drainage network design [95]. This is one of a number of studies that Swaffield and Galowin undertook, culminating in a book called the engineered design of building drainage systems [96].

- Swaffield and Galowin presented a paper entitled Investigation of apparent limits of drainline waste transport with low volume flush water closets [97].

- Swaffield and McDougall presented a paper at the International Conference on Sewer Solids entitled Modelling solid transport in building drainage systems [24].

- Wise and Swaffield co-authored on Water, Sanitary and Waste Services for 
Buildings [98].

- Swaffield discussed Transient airflow in building drainage systems [25].

Given the extent of the overall research collaborations with Swaffield, there is wide scope for review; however, the collaborations reported herein concentrate on the link with Swaffield and LSTD investigations.

\subsection{Swaffield and Galowin}

Whilst carrying out tests to investigate water conservation, Galowin used plastic cylinders to mimic human faeces [99]. McDougall and Swaffield refer to the standard faecal stool as being $76 \mathrm{~mm}$ long and $38 \mathrm{~mm}$ in diameter with a specific gravity of 1.05 [57]. This is the NBS Solid referred to by Bokor [6] in Section 3 and is constructed from non-organic material.

A concept known as LSTD is referred to by Littlewood [29]. This concept for a solids/flush appears to have been addressed by Swaffield and Galowin [97] and, when referring to their computer model and the use of a 6.0 litre WC flush, they state "almost no limits occur for transport of waste solids" for given drainlines. This statement is somewhat qualified by references to the computer model not taking account of certain aspects of the system including junctions and the authors ask the questions "Is there an unresolvable dilemma or can understanding of the installation/operating conditions or the physical fundamentals explain the set of findings?". It is evident that this question remained unanswered as Swaffield [3] appears to have a revised view of the LSTD and states the following:

"Solid velocity depends on surrounding flow conditions. As the flush attenuates solid deposition occurs. This implies that for one w.c. in one pipe of fixed slope, diameter and roughness and where there is no other supporting flow, there is a MAXIMUM travel distance for any solid regardless of how many times the w.c. is flushed".

This statement was made showing a $150 \mathrm{~mm}$ diameter sewer at a gradient of $1 / 100$.

\subsection{Swaffield and McDougall}

McDougall and Swaffield presented research on the influence of water conservation on drain sizing for building drainage systems [50]. This simulation based work looked at house types and flow patterns and concluded that lower flows from WCs will lead to increased maintenance costs unless designs are revised. McDougall concluded that the simulation tool presented would be beneficial for designers. McDougall also worked with Wakelin (see Section 2) and jointly published a paper in 2007 that looked at the influence of flush volume on deformable solid transport. In this paper, McDougall and Wakelin [53] refer to "reanalysis of the major data set". It appears that the major data set used is data included from Wakelin's doctoral thesis which is cited in the references. The test apparatus used is shown in Figure 2 and shows the range of pipes and channels used. McDougall and Wakelin report the use of a deformable solid and detail three zones in the branch line created by the change in shape of the deformable 


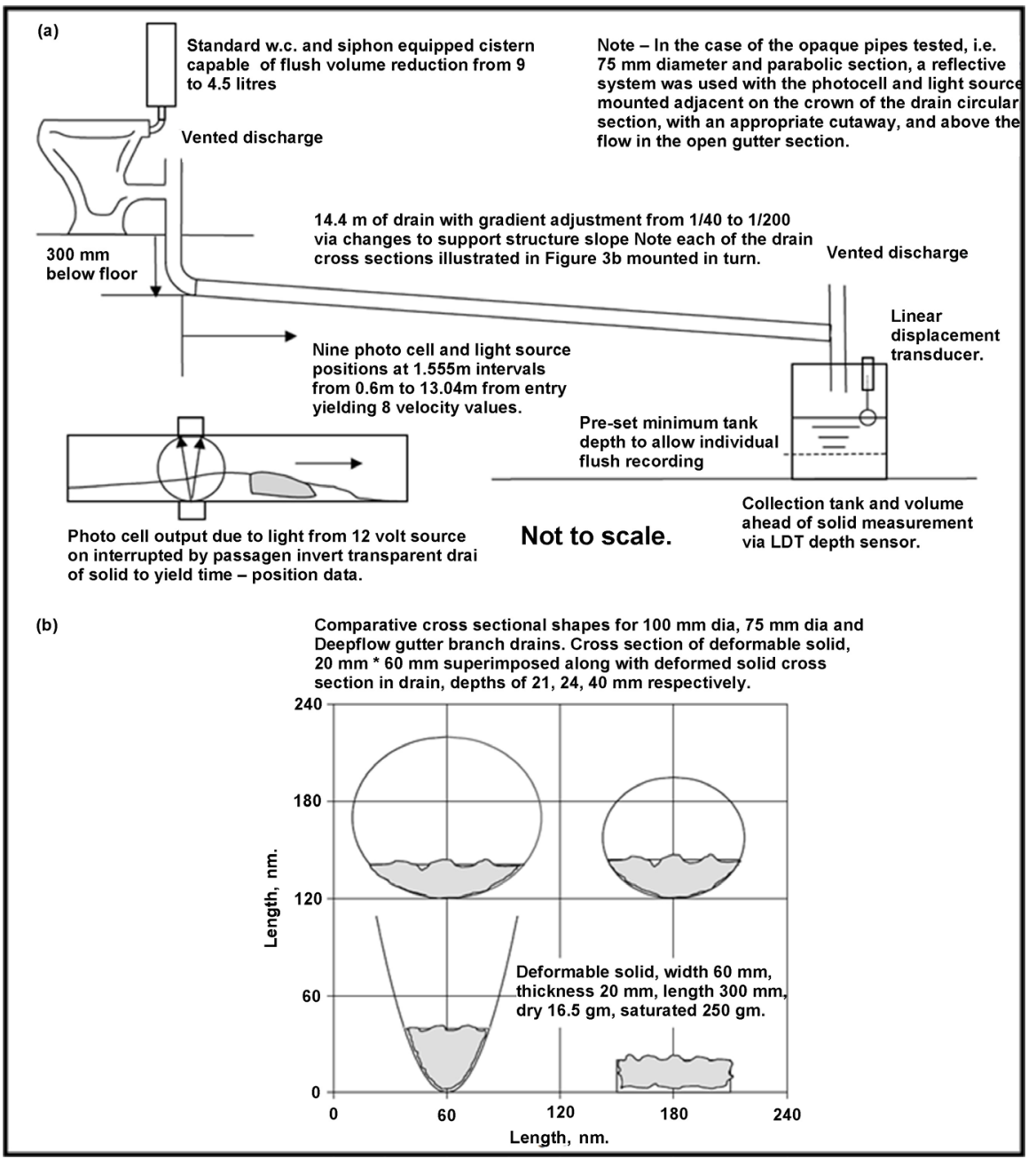

Figure 2. Experimental test-rig including cross sectional branch shapes [53].

solid as shown in Figure 3 [53]. These zones are based on previous work reported in Wakelin's doctoral study dated 1978 [5].

\subsection{Non-Circular Pipes}

Cummings, Swaffield and Wakelin presented research on hydraulic assessment of non-circular-section building drainage [26]. This was not the first time that Swaffield was involved in looking at research into alternative drain cross sections as reference was made to Swaffield completing a consultancy project in this area in 1997 [26]. The 2007 research provides results from solid transfer in a range of pipe diameters, including $75 \mathrm{~mm}, 100 \mathrm{~mm}$ and a parabolic gutter; it appears that the parabolic gutter is the gutter referred to in Figure 3 reported by McDougall and Wakelin [53]. The paper also provides two concept non-circular shapes referred to as Concept 5 and Concept 6 shown in Figure 4.

Whilst reference is made to ovoid or "egg shaped" sewers within the research, none of the non-circular concepts including the parabolic gutter match the geometry of either the standard (wide or metropolitan egg) or the new (narrow 


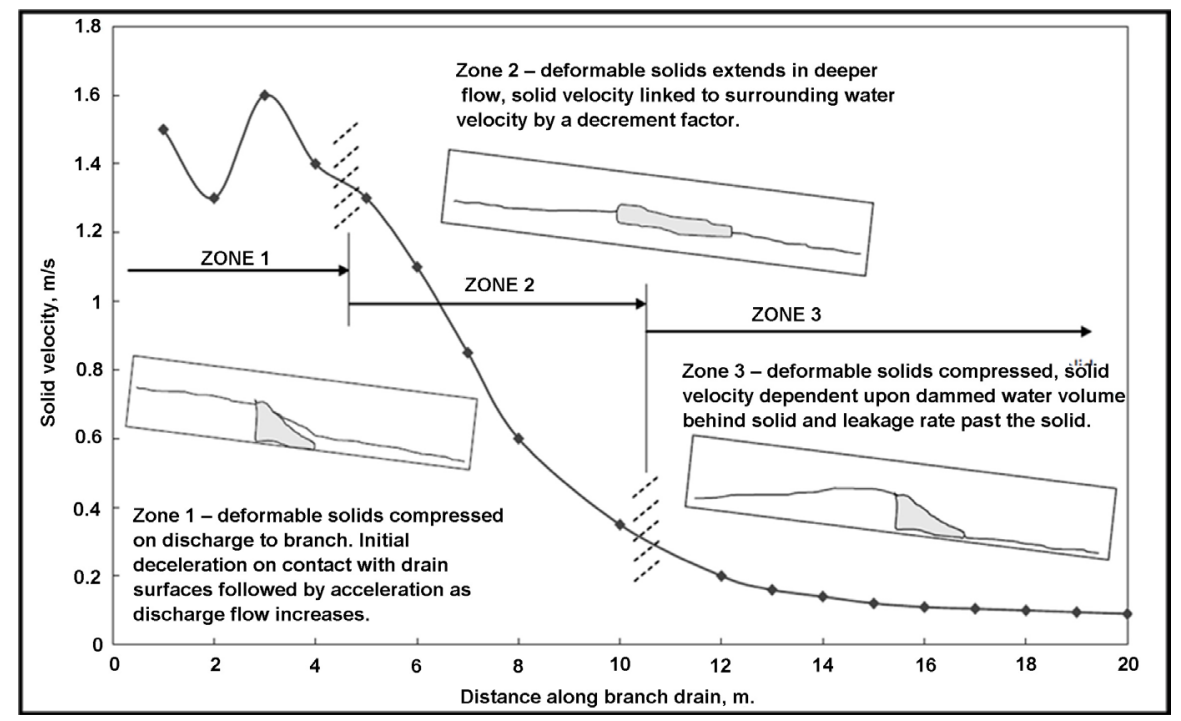

Figure 3. Zonal description of solid transport [53].

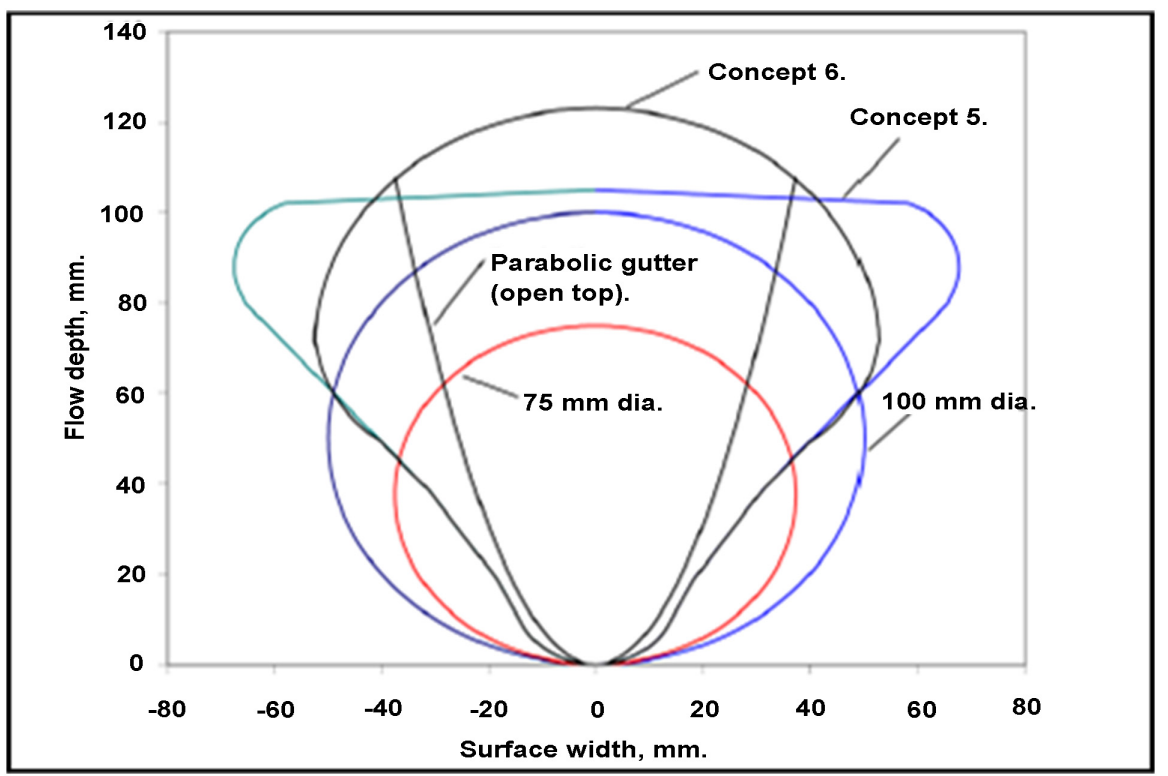

Figure 4. Comparison of cross section shapes [26].

egg). However, the parabolic gutter is a similar concept to the egg-shaped pipe approach. The paper demonstrated that non-circular pipes can give increased solid travel distances of more than $50 \%$ at gradients of $1 / 100$. Whilst the paper did not specifically call for further research in the area of non-circular pipes, it is implied by making reference to the need to research innovative drainage networks, with increased travel distances, illustrating that this is a significant area where research is required. An increase in the use of wipes, due to a change in personal hygiene habits and subsequent flushing through sewer systems, is explicitly stated as an area that should be researched in the future.

In terms of the use of non-circular pipes for sanitation, there have been parabolic pipes found in Knossos, Crete that date back to $1600 \mathrm{BC}$, according to Ber- 
trand-Krajewski [100]. The majority of detailed historical accounts of the use of non-circular/egg-shaped pipe relate to the Victorian era. According to Curthoys [101], John Roe was the first to introduce the concept of egg-shaped pipes whilst working as surveyor (of sewers) in the Holborn and Finsbury districts of London (1831-1847). Roe had an interest in sewer self-cleansing velocity in order to reduce blockages and, circa 1845, experimented with pipes that had narrower invert radius than the crown radius. Roe concluded that forcing the waste material through a lesser space increased the velocity and therefore assisted in waste material being carried in the sewer by keeping waste material in suspension for longer distances. Roe specified ovoid or egg shaped sewers for many drainage schemes in London. Roe's work and associated views was referenced in Edwin Chadwick's report entitled Sanitary Condition of the Labouring Population in Britain which was published in 1842 (Chadwick, 1842) [102]. In 1848, Roe was given the position of Chief Surveyor of the London Metropolitan Commissioners of Sewers. Marriott [103] supports Curthoys [101] in terms of John Roe being the inventor of the egg-shaped pipes and adds that Isambard Kingdom Brunel expressed reservations whilst commenting on Roe's research on the flow velocity gain in an egg-shaped pipe compared with a circular sewer pipe.

\subsection{Low Flush Volumes}

Jack and Swaffield state that "efficacy and efficiency in drainage provision need not be subjected to 'over-design', i.e. through excessive water use' [36]. This statement is based on an overview of drainage systems' developments. McDougall and Wakelin conclude that proposed flush volume reductions to 4 litres and below are feasible [53]. This is based on the research reported in 6.4. This flush reduction judgement is supported by the work of Gauley and Koeller qualified by reference to supplemental flows from showers and washing machines [33]. Swaffield et al. [21] completed research in conjunction with Twyford on a low flush WC for developing countries and prototype testing concluded that the WC was as efficient as the comparable British standard $9 \mathrm{~L} \mathrm{WC}$ in terms of flush capacity. According to Swaffield and Wakelin, "The lower limit for successful toilet cleansing and solid transport has historically been shown to be at or less than 3 litres" [104].

\subsection{Recommendations for Further Work}

In Cummings et al. [26] which included Swaffield, recommendations for further work into innovative drainage networks were implied while discussing the use of non-circular sewers. Comments were made by Swaffield [3] [4], implying that research in the area of solid transport in sewers as being completed, is given in Section 9.4.

\section{Littlewood}

\subsection{Introduction}

The aim of Littlewood's study was to research if the reduction in pipe diameters 
could increase carrying capacity of flush waves when considering intermittent flows. The study also considered if the diameter reduction would increase pipe blockages and was entitled "Movement of Gross Solids in Small Bore Sewers". The study resulted in a computer model of solid movement under intermittent flow. The model was verified by an extensive programme of practical experiments. Results derived from the model were used in the WRc review of Part Hof the Building Regulations. Littlewood [29], Littlewood and Butler [30] [31] and Littlewood et al. [32] used the "Westminster Solid" which is based on the NBS solid referred to in Section 6. Littlewood used varying solid sizes which also allowed mimicking stages of solid degradation and these sizes, along with the specific gravities used, are shown in Table 7.

Among the variety of tests which Littlewood [29] carried out, tests on toilet paper using 5 sheets and 10 sheets were conducted separately and also used combination solids which consisted of combinations of Westminster solids with toilet paper.

\subsection{Influence of Toilet Paper}

Ashley et al. [105] (cited in Arthur et al. [63]) made reference to the intermittent flows experienced by small catchments and that the upstream section of catchments can result in solid transfer movement being start and stop over time as opposed to being continuous. Littlewood identified a stoppage as deposited material in a pipe and provided examples of how a stoppage could form a blockage [29]. This included the scenario that if no other flush wave occurs for a given period and, if a deposited solid is allowed to dry and harden, this could stop subsequent solids. Significant factors on the role of toilet paper in solids' movement and flush mechanisms were reported by Littlewood [29] and the main findings of the tests carried out on toilet paper are as follows:

- Increased flush volumes provide increased toilet paper velocity and flush distance.

- The velocity and distance travelled of 10 sheets was less than that of 5 sheets of toilet paper.

- There was no LSTD established within the $25 \mathrm{~m}$ length of the test rig/pipe.

- Wave intensity does not necessarily affect toilet paper.

- Smaller pipe diameter provides increased toilet paper velocity and flush distance, with more predictable results.

The main findings for combination solids by Littlewood [29] show the positive impacts that toilet paper can have on solid transfer in sewers, some of which are as follows:

- Solid movement is significantly influenced by the size of the toilet paper dam.

- Westminster solid travel distances increase when toilet paper is added to a flush.

- Large Westminster solids (as part of a combination) move with a lower velocity than those with smaller Westminster solids and with reduced distance of solid travel for equal volume flushes.

- Higher specific gravity combination solids reduce the distance of solid travel for equal volume flushes. 
Table 7. Westminster solid [29].

\begin{tabular}{ccccc}
\hline Reference code & Length $(\mathrm{mm})$ & Diameter $(\mathrm{mm})$ & Specific gravities $\left(\rho / \rho_{w}\right)$ & Colour \\
\hline LW & 80 & 38 & 1.05 & white \\
MW & 44 & 20 & 1.05 & white \\
SW & 22 & 10 & 1.05 & white \\
LB & 80 & 38 & 0.97 & black \\
MB & 44 & 20 & 0.97 & black \\
SB & 22 & 10 & 0.97 & black \\
\hline
\end{tabular}

- Larger flush volumes increase distances of solid travel.

- Smaller pipe diameters increase the initial solid velocity and the distance moved for a particular solid/wave combination.

- The solid movement mechanism for a combination of solids depends on the amount of water (if any) behind the solid.

\subsection{Defects in Construction Quality}

Littlewood suggests that a deviation in flow depth of "as little as $1 \mathrm{~mm}$ " could cause a solid to deposit [29]. Flow depths change for a number of reasons including water volume and velocity, pipe roughness, pipe diameter and gradient. Construction defects are also a cause of flow depth changes through disrupting flow because of poor pipe jointing techniques.

Littlewood [29] refers to workmanship in sewers being an "important factor" to allow sewers to operate effectively and points out that BS $8301 \mathrm{~S} 7.4 .4 .4$ states that gradients may be relaxed a little if the standard of workmanship is good, from $1 / 80$ for $100 \mathrm{~mm}$ diameter pipes to $1 / 130$. This suggests that shallower gradients require "good workmanship". The construction quality issue has been identified by a number of authors as shown in Table 4.

\subsection{Shape Factor}

Littlewood [29] introduced the "shape factor" $(\Omega)$ and states that the shape factor can be defined as the percentage of the flow area which is occupied by the solid:

$$
\Omega=\frac{A_{s}^{*}}{A_{f}}
$$

The shape factor is illustrated in Figure 5 and takes account of the variability of shapes created, for example, by toilet paper only and combination solids. where

$A_{s}^{*}=$ solid end area occupying the flow area.

$A_{f}=$ total flow area.

Littlewood found that shape factors of $50 \%$ - $80 \%$ were common in larger pipe diameters, and that high shape factors of $95 \%$ were less likely to occur in larger diameter pipes [29]. Increases in shape factor relate to an increase in the 


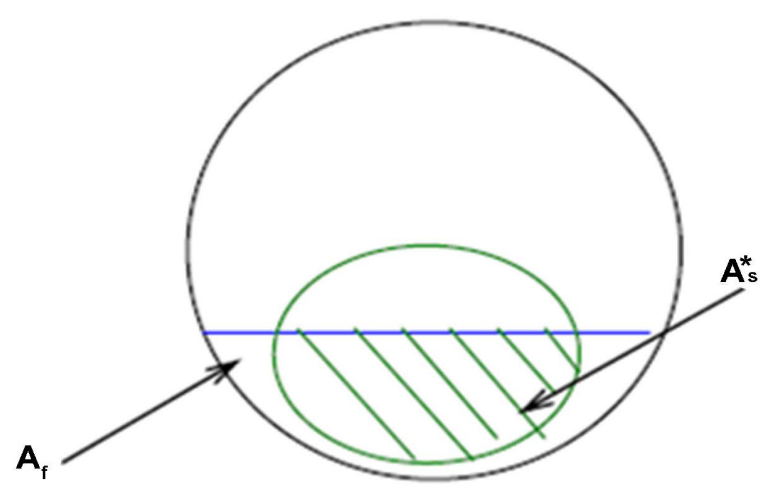

Figure 5. Shape factor definition [29].

upstream solid area thus increasing the force on the solid due to increased water being dammed behind the solid, therefore creating conditions to assist with the increasing of solid transfer distances. Littlewood also highlighted the "sliding leaking dam" that relates to solid movement with varying quantities of the dammed water (behind the solid) leaking past the solid while the solid is sliding along the invert of the pipe [29].

\subsection{Limited Solid Transport Distance}

Littlewood found that the LSTD increased for the same flush and given solid combination through a decrease in pipe diameter [29]. This statement was qualified by Littlewood and Butler [30], making reference to the possible plugging of small diameter pipes having an effect on the limit that solid can be transported, reporting that the sanitary towels tested as part of the experimental programme did not move in the $50 \mathrm{~mm}$ pipe whilst having very limited movement in the 75 mm pipe. The LSTD referred to by Littlewood [29], Littlewood and Butler [30] [31], Butler et al. [14] [15], Memon et al. [54] and Swaffield [3] [4] was identified through the use of non-organic material. Littlewood et al. investigated the downstream implications of ultra-low flush WCs describing the "ultra-low" flush volume as under 2 litres [32]. The investigation found that there was potential to use ultra-low WCs highlighting the need for revised design rules for the associated sewerage system, the conclusion makes reference to consideration of the location of the "nearest connected appliance" to the WC.

\subsection{Recommendations for Further Work}

Littlewood [29] provided a detailed account of recommendations for further research which are summarised herein and include:

- The effect of junctions and bends to assess solids' movement with a sliding, leaking dam mechanism.

- Further testing on clay pipes to determine the effect of pipe materials on solid movement.

- Investigating the coalescing of multiple solids in the sewer including the effect on LSTD. 
- Self-cleansing velocity in relation to maximum distances of pipes design relating to the sliding, leaking dam mechanism zones.

- The effect of pipe gradient on the movement of solids within the sliding, leaking dam zone.

\section{Gauley}

\subsection{Introduction}

Whilst the majority of low flush rig-based testing has been carried out in the UK, a Canadian researcher (Bill Gauley) has carried out rig-based testing to determine the impact of reduced flushes. Gauley has also trialled a number of different materials in order to simulate human faeces. Gauley has carried out the testing of WCs in terms of efficiency and the ability to evacuate solids from the bowl. This work is still ongoing and is wide ranging because of changes in WC flush technologies and cistern design.

\subsection{MaP testing}

A significant amount of work has been completed by Gauley in relation to testing the performance of WCs. Gauley and Koeller refer to this work as Maximum Performance (MaP) testing [106]. The work undertaken by Bill Gauley (a Water Engineer) in the area of testing WCs is reported in The Big Necessity by George [107] who provides the following account relating to Gauley not being satisfied with the industry norm in the use of sponges to test toilet performance. Gauley wanted to come up with "realistic test media" and tried various organic materials including rice paste, peanut butter, potatoes, flour and water and mashed bananas. Gauley heard that soybean paste was one of the ingredients used by TOTO which was one of the world's leading toilet manufacturers in testing their toilets; however, TOTO would not confirm the exact recipe. Eventually miso soybean paste was tested by Gauley's crew and Gauley was satisfied that this was a reasonably close match to human faeces. George reports that "Not that we go around feeling faeces but some of us have kids and it seemed right for density and moisture content" [107]. In 2010, Gauley produced a methodology for Maximum Performance Testing of toilets in which he provided a methodology for using the soybean paste. The soybean paste was also used by Gauley in 2005 to perform rig-based testing to look at the area of solid transfer in low flows.

\subsection{Evaluation of Low Flush Toilets}

Gauley and Koeller produced a report called the Evaluation of Low-Flush-Volume Toilet Technologies to Carry Waste in Drainlines [33]. The report was completed for the Canadian Mortgage and Housing Corporation. The test apparatus used was a $24.4 \mathrm{~m}$ test-rig. Each flush used $200 \mathrm{~g}$ of extruded soybean in order to represent human faecal matter. The density of the soybean was not specified in Gauley's work but George [107], when discussing the work of Gauley and the use of soybean paste, reported that Gauley said it "looked and floated right" with 
the suggestion being that the specific gravity may have been 1.0 at a maximum. Gauley was contacted by the author of this paper to enquire about the density of the soybean used by Gauley and Koeller [33]. Gauley confirmed that the relative density of the soybean paste was approximately 1.20 and went onto say that "We have also, on occasion, produced 'floating media' by adding some powdered styrofoam to the paste to reduce the density" [108].

Gauley makes reference to the work of Swaffield within the 2005 report and draws comparisons between the Swaffield and Galowin study by showing that the flush travel distance is more affected by pipe gradient than pipe diameter [97]. Gauley also shows that the results obtained correlate to what Swaffield and Galowin found in relation to the impact of the second flush or subsequent flushes and the impact of same on travel distance.

Unassisted flushing technology (gravity only) provides the least impact in terms of evacuation of the bowl when compared with power assisted. The reason for choosing gravity only in the research is that gravity wash-down WCs are the most popular in the UK. By comparing Gauley's earlier MaP testing of toilets and the low flush testing, it was confirmed by Gauley that there was no correlation between the ability of a toilet to evacuate a large mass of solids and flush distance achieved as shown in Table 8.

The Gauley and Koeller [33] report concluded that "Under expected and required conditions virtually all 6 litre (1.6 gallon) and even 4 litre (1.1 gallon) toilets should meet or exceed household requirements regarding sewage flow even with no supplemental flows (e.g. from showers or clothes washers)". Gauley goes on to comment on the likely causes of blockages to problems with the construction of sewers including jointing and alignment.

\subsection{Recommendations for Further Work}

Gauley and Koeller [33] made a number of recommendations for "possible" further work which are summarised as follows:

- Other flows such as washing machines, dishwasher, sinks and dishwashers.

- The effects of different types of pipes including cast iron salvaged piping from buildings that were going to be demolished.

- Testing of sanitary products.

- Carrying out the tests using toilets that are only capable of evacuating $200 \mathrm{~g}$ or less from the bowl.

- Testing using different test media.

- Allowing the media to dry in the line to simulate weekend or vacation periods.

\section{Other Rig-Based Research}

\subsection{Introduction}

A number of rig-based research projects have been completed in the past decade. The EA has also reported on a number of rig-based research, the most significant of these are summarised herein. 
Table 8. Solid carry distance versus evacuation from WC bowl [33].

\begin{tabular}{ccc}
\hline Flushing technology & $\begin{array}{c}\text { Average carry } \\
\text { distance }(\mathrm{m})\end{array}$ & $\begin{array}{c}\text { MaP testing results } \\
\text { (g of evacuated material) }\end{array}$ \\
\hline Pressure-Assist-6.0-L & 20.1 & 900 \\
Gravity-Rim Jet & 16.3 & 550 \\
Gravity & 14.9 & 900 \\
Gravity-Siphon Jet in Sump of Bowl & 14.8 & 325 \\
Gravity-Siphon Jet in Trapway & 14.0 & 375 \\
Gravity-Tipping Bucket & 15.0 & 725 \\
Gravity-Washdown & 10.9 & 650 \\
Gravity-Vacuum-Assist & 8.1 & 500 \\
\hline
\end{tabular}

\subsection{Environment Agency}

The EA report entitled Less Water to Waste considered existing rig-based testing research that had been carried out [1]. The report called for more informed guidance to ensure that "water efficiency" is analysed whilst also looking at the "bigger picture" in terms of considering sewer design. The EA [1] made reference to a considerable amount of rig-based researchers including Gauley and Koeller [33], McDougall and Swaffield [50], Littlewood and Butler [31], and Littlewood et al. [32]. The EA also referred to the practical experimental work on solids' movement in drains, when comparing Gauley and Koeller's [33] Canadian study to the UK study of Littlewood and Butler [31] as providing consistent results. The EA report made recommendations for further work, including rig-based testing to investigate combinations of optimum pipe types, diameters and gradients for solid movement in low flow situations. The EA report outlined that most blockage problems associated with solids' movement happen where limited wastewater discharges occur and gave examples including a small number of properties (small catchments) and single properties.

The EA report agrees with Littlewood [29], Arthur et al. [63] and Marlow et al. [66] that lower wastewater discharges increase the probability of blockages occurring and state that "the trend towards more singleoccupancy properties may have as great an impact on the potential for sewer blockages as the drive to reduce water consumption" [1]. It also recommended that designs should allow for these situations and that practical investigations should be carried out on pipelines serving one or two/three, single occupancy properties. The EA report also referred to the impact of domestic appliances on water use but stated that "none have reported on the impact on sewer system performance" [1]. This implied that no research consensus has been reached on the impacts of baths despite researchers agreeing that the bath is significant in terms of discharge impact on sewers. This is in part due to a lack of factual information or research to show that bath discharges alone can move solids along a pipe. 


\subsection{Gormley}

Gormley and Campbell reported on the transport of solids in above ground drainage using a rig which tested $14.0 \mathrm{~m}$ of pipe (between loading junctions) to develop a model to predict a surge wave in a pipe [52]. Using the rig as described in Gormley and Campbell [52], Gormley and Campbell [109] looked at the effects of surfactant dosed water on solid transfer and found that solid transfer velocity can be increased by as much as $16 \%$. This called for further work to calculate a "surfactant effect coefficient".

\subsection{Plumbing Efficiency Research Coalition}

The Plumbing Efficiency Research Coalition (PERC) produced The Drainline Transport of Solid Waste in Buildings report which used a test-rig consisting of a total length of $41.0 \mathrm{~m}$ of $100 \mathrm{~mm}$ diameter clear plastic pipe [110]. The choice for the pipe configuration on the test-rig was not given. The report used Gauley's MaP testing as referred to in Section 8.2 in terms of the media used. The amount of toilet paper used per flush was also regarded as a significant part of the PERC study [110] and refers to the work of Cummings [28] who looked at variability of solid transport distance in sewers, using a reported 22 types of toilet paper available in the Australian market.

PERC [110] refers to Swaffield [3] who presented at the Dry Drains Forum in Germany and states the following:

"We highlight Professor Swaffield's presentation, inasmuch as the thesis of his presentation was that adequate research on the topic of drainline transport had already been conducted (implying, therefore, that further such research was unwarranted). Later, this thesis was repeated in another paper and presentation he provided for the 2009 CIB-W062 conference in Düsseldorf, Germany, in which he specifically referred to the recently announced PERC Drainline study effort as unnecessary".

PERC [110] went on to divulge that a dialogue opened up between PERC member Pete DeMarco and Swaffield, with DeMarco highlighting that the PERC study was unique in terms of attempting to rank variables within solid transport in drainlines and reports that Swaffield was intrigued by this prospect. The results of the PERC study were published in November 2012 [110]. PERC concluded that the most significant variables in solid transport in drainlines (based on the tests they carried out) are pipe gradient followed by type of toilet paper used then flush volume [110]. The non-significant variables include percentage of trailing water and then flush rate (velocity) with each variable presented as a hierarchy (Table 9).

Aspects of the PERC [110] findings are both supported and disputed by previous research. For example, Lillywhite and Webster [7] concluded that the incidence of blockages did not seem to be "seriously" influenced by the sewer gradient. In order to assess the hierarchy of variables presented by PERC [110], collated information from Table 4 in terms of the causes of sewer blockages are 
Table 9. PERC variables compared with sewer blockages factors.

\begin{tabular}{|c|c|c|c|}
\hline $\begin{array}{l}\text { Variable or } \\
\text { factor } \\
\text { reference No. }\end{array}$ & $\begin{array}{l}\text { Variables that influence } \\
\text { solid transport and } \\
\text { factors identified that can } \\
\text { lead to pipe blockages }\end{array}$ & $\begin{array}{l}\text { No. of authors } \\
\text { agreeing with the } \\
\text { variable or factor }\end{array}$ & Author and year \\
\hline \multicolumn{4}{|c|}{ Significant variables (PERC 2012) } \\
\hline SV1 & Pipe gradient & 3 & $\begin{array}{l}\text { Flat gradients are identified by Arthur et al. [63], Fenner et al. [59] and } \\
\text { Rodriguez et al. [60] as a cause of sewer blockages. This is not supported by } \\
\text { Lillywhite and Webster [7]. }\end{array}$ \\
\hline SV2 & Toilet paper used & 4 & $\begin{array}{l}\text { Toilet paper has been identified by Littlewood [29] and Cummings [28] as a } \\
\text { factor in solid transport, by implication toilet paper is a factor in solid } \\
\text { deposition and solid deposition is a blockage factor which is identified by } \\
\text { Arthur et al. [63] and Fenner et al. [59]. }\end{array}$ \\
\hline SV3 & Flush volume & 3 & $\begin{array}{l}\text { Flush volume is a factor in solid transport, by implication a factor in solid } \\
\text { deposition which is identified by Arthur et al. [63], Fenner et al. [59] and } \\
\text { Littlewood [29]. }\end{array}$ \\
\hline \multicolumn{4}{|c|}{ Non-significant variables (PERC 2012) } \\
\hline NSV1 & $\%$ of trailing water & 0 & $\begin{array}{l}\text { In the blockage factors } \% \text { trailing water has not been explicitly provided as a } \\
\text { cause of blockages; however, Table } 3.10 \text { which is an update of this table to } \\
\text { include rig-based research includes specifics in relation to } \% \text { trailing water. }\end{array}$ \\
\hline NSV2 & $\begin{array}{l}\text { Flush rate } \\
\text { (velocity) }\end{array}$ & 2 & $\begin{array}{l}\text { Flush velocity is related to self-cleansing velocity, self-cleansing velocity has } \\
\text { been identified by Arthur et al. [63] and Littlewood [29] as a factor in sewer } \\
\text { blockages. }\end{array}$ \\
\hline \multicolumn{4}{|c|}{ Blockage factors from Table 4} \\
\hline BF1 & Age of sewer & 2 & $\begin{array}{l}\text { Davies et al. [69] and Rodriguez et al. [60] cite sewer age as a factor in sewer } \\
\text { blockages. }\end{array}$ \\
\hline BF2 & Depth of cover & 4 & $\begin{array}{l}\text { Davies et al. [69], Fenner et al. [59], Marlow [66] and Rodriguez et al. [60] } \\
\text { agree that depth of cover influences sewer blockages. This is mainly due to two } \\
\text { factors including deformation or collapse of shallow sewers when loaded and } \\
\text { tree root penetration. }\end{array}$ \\
\hline BF3 & Fats, oils and grease & 4 & $\begin{array}{l}\text { Fats, oils and grease have been identified by Davies et al. [69], Fenner et al. } \\
\text { [59], Littlewood [29], Marlow [66] and Rodriguez [60] as having influence } \\
\text { on sewer blockages. }\end{array}$ \\
\hline BF4 & Joint/material type & 3 & $\begin{array}{l}\text { Davies et al. [69], Lillywhite and Webster [7] and Marlow [66] all identify joint } \\
\text { type and material pipe type as factors in sewer blockages. }\end{array}$ \\
\hline BF5 & Junctions & 3 & $\begin{array}{l}\text { Junctions have been identified by Arthur et al. [63], Lillywhite and Webster [7] } \\
\text { and Littlewood [29] as a factor that can lead to blockages. }\end{array}$ \\
\hline BF6 & Ground conditions & 3 & $\begin{array}{l}\text { Davies et al. [69], Fenner et al. [59] and Marlow [66] agree that ground } \\
\text { conditions can cause adverse pipe movement leading to misalignment } \\
\text { or back falls leading to sewer blockages. }\end{array}$ \\
\hline BF7 & Gross solids/misuse & 5 & $\begin{array}{l}\text { Arthur et al. [63], Lillywhite and Webster [7], Littlewood [29], Marlow [66] } \\
\text { and Rodriguez et al. [60] all cite misuse of sewers through flushing items such } \\
\text { as nappies as a cause of sewer blockages. }\end{array}$ \\
\hline BF8 & Intermittent flow & 3 & $\begin{array}{l}\text { Arthur et al. [63], Littlewood [29] and Marlow [66]all cite intermittent flow as } \\
\text { a cause of sewer blockages. }\end{array}$ \\
\hline BF9 & Length of sewer & 3 & $\begin{array}{l}\text { Arthur et al. [63], Fenner et al. [59] and Rodriguez et al. [60] refer to length of } \\
\text { sewer as a cause of sewer blockages. }\end{array}$ \\
\hline BF10 & Small dia. pipe & 4 & $\begin{array}{l}\text { Arthur et al.[63], Fenner et al. [59], Marlow [66] and Rodriguez et al. [60] } \\
\text { report that sewer blockages occur more frequently in small diameter pipes, } \\
\text { usually in pipes of } 150 \mathrm{~mm} \text { diameter or less. }\end{array}$ \\
\hline
\end{tabular}

Notes: $\mathrm{SV}=$ Significant Variable 1; NSV = Non Significant Variable; BF = Blockage Factors. 
listed against the significant and non-significant variables from PERC [110] which are shown in Table 9.

There appears to be a wide range of variables that can affect solid transport, thus possibly causing sewer blockages even when excluding obvious causes such as tree roots (identified by six researchers) and quality of construction (identified by four researchers) which have been excluded from Table 9. The non-significant variables found by PERC (2012) [110], i.e. the percentage of trailing water and the flush rate disagree with Swaffield's (2009) [3] [4] findings which concluded that the trailing water or flush volume discharged behind the solid is probably the most important parameter. This is clear evidence that there is no worldwide general consensus among researchers in relation to some of the fundamental issues. Swaffield also reports and concludes that solid transport decreases due to reasons such as solid mass increase, solid specific gravity increase, solid cross-sectional area increase and drain diameter increase [3] [4].

The PERC report [110] gives areas where future study is required. For example, it points out that clear plastic pipes (referring to their own test rig) are not used in building drainage and calls for commercial pipes to be used in future testing whilst being able to maintain visual observation. PERC also recommends that further work be carried out on "so called flushable" consumer products to investigate the impact on drains. The first recommendation made by PERC was that testing should be carried out on a $75 \mathrm{~mm}$ diameter pipe and they regard this work as being essential [110]. However, significant research on solid transfer in $75 \mathrm{~mm}$ nominal bore pipes has already been carried out and reported by Littlewood [29], Littlewood and Butler [30] [31], Butler et al. [14] [15] and McDougall and Wakelin [53]. Indeed, Littlewood's [29] research included a substantial amount of testing in relation to the impact of toilet paper (reported in Section 7.2) and included rig-based testing of a $75 \mathrm{~mm}$ nominal bore pipe. This research appears to have been overlooked by PERC given that they have recommended research on testing of $75 \mathrm{~mm}$ nominal bore pipes which Littlewood completed over 12 years previously in 2000 . Oversights like this may be due to the geographical separation between the UK and the US but remains surprising given that the PERC report [110] included the EAreport [1] (referred to in Section 9.2) in their list of references and Littlewood's research is the most frequently referred to research in the EA report [1], being mentioned more than ten times within the main text. It could be argued by PERC that the variability of toilet paper type would warrant further investigation in terms of the testing of small bore pipes such as $75 \mathrm{~mm}$ diameter to further develop research in this area. This would result in adding further knowledge to Littlewood's research in this area [29]. Whilst PERC [110] presented a number of findings, the most significant outcome according to the report could be an increased amount of discussion between interested parties in this research area. Given the fact that PERC [110] missed out on Littlewood's research, this would appear to be an important outcome. Table 10 summaries areas researched in terms of solids' transfer through rig-based testing. 
Table 10. Areas researched in terms of solids' transfer through rig-based testing.

\begin{tabular}{|c|c|c|c|c|c|c|c|c|c|c|c|}
\hline \multirow{2}{*}{ Gap ID } & \multirow{2}{*}{ Area researched } & \multicolumn{10}{|c|}{ Researchers and areas that they have investigated } \\
\hline & & Bokor & Butler & Cummings & Gormley & Gauley & Lillywhite & Littlewood & PERC & Swaffield & Wakelin \\
\hline 1.0 & Forces on solids & $\checkmark$ & $\checkmark$ & & & & & $\checkmark$ & & $\checkmark$ & $\checkmark$ \\
\hline 2.0 & Influence of TP & & & $\checkmark$ & & & & $\checkmark$ & $\checkmark$ & & \\
\hline 3.0 & LSTD & & $\checkmark$ & & & & & $\checkmark$ & & $\checkmark$ & \\
\hline 4.0 & $\begin{array}{l}\text { WC usage } \\
\text { behaviour }\end{array}$ & & $\checkmark$ & & & & $\checkmark$ & & & $\checkmark$ & \\
\hline 5.0 & WC type & & & & & & & & & $\checkmark$ & \\
\hline 6.0 & WC flush volume & & & & & & & $\checkmark$ & & $\checkmark$ & \\
\hline 7.0 & Pipe configuration & & & & & & & & & $\checkmark$ & \\
\hline 8.0 & Pipe dimensions & $\checkmark$ & $\checkmark$ & $\checkmark$ & $\checkmark$ & $\checkmark$ & $\checkmark$ & $\checkmark$ & $\checkmark$ & $\checkmark$ & $\checkmark$ \\
\hline 9.0 & Pipes (non-circular) & & & & & & & & & $\checkmark$ & \\
\hline 10.0 & Pipe gradient & $\checkmark$ & $\checkmark$ & $\checkmark$ & $\checkmark$ & $\checkmark$ & $\checkmark$ & $\checkmark$ & $\checkmark$ & $\checkmark$ & $\checkmark$ \\
\hline 11.0 & Simulated faeces & $\checkmark$ & & & & $\checkmark$ & & & $\checkmark$ & $\checkmark$ & \\
\hline 12.0 & Faeces degradation & & $\checkmark$ & & & & & & & & \\
\hline
\end{tabular}

Note: $\mathrm{TP}=$ Toilet Paper.

\section{Conclusions}

Water conservation is critical in order to assist in providing sustainable development in a UK context. When considering climate change, in terms of the availability of raw water, there is uncertainty for the UK population which is predicted to increase from 63.7 million in 2012 to 73.7 million in 2037 [111]. In addition, sustainability indicators for the UK water industry show an increased trend in greenhouse gas emissions and an increase in the number of UK properties affected by sewer flooding. These population increases, growing climate change impacts and water security issues are also reflected in global commentary and assessments.

Along with water conservation being critical, continued research addressing the effects that less water to waste has on solid transfer in sewers is critical. Table 11 provides 11 research gaps that have been identified by previous low flow investigations and rig-based testing. The Test Rig shown in Figure 6 has been used between 2012 and 2018 to address gaps in the research and has allowed development of the following 5 research studies which are as a result of extensive rig-based testing:

1) Production of a "Simulated Solid" to mimic human waste for testing Sewers: this study shows how human faeces are tested to allow development of a simulated solid that mimics human faeces.

2) Performance of non-circular sewers in delivering reduced water consumption: this study reports on the performance of small diameter "egg shaped" sewers.

3) Degradation of human faeces in sewers: this study reports on sewer degradation mechanisms associated with human faeces transfer in foul sewers. 
Table 11. Gaps identified by rig-based testing.

\begin{tabular}{|c|c|c|c|c|c|c|c|c|c|c|c|}
\hline \multirow[b]{2}{*}{ Gap ID } & \multirow[b]{2}{*}{ Gap identified } & \multicolumn{10}{|c|}{ Researchers and the research gaps identified } \\
\hline & & Bokor & Butler & $\begin{array}{l}\text { Environment } \\
\text { agency }\end{array}$ & Gormley & Gauley & Lillywhite & Littlewood & PERC & Swaffield & Wakelin \\
\hline 1.0 & $\begin{array}{l}\text { Effect of junctions } \\
\text { and bends }\end{array}$ & $\mathbf{x}$ & & & & & $\mathbf{x}$ & $\mathbf{x}$ & & & $\mathbf{x}$ \\
\hline 2.0 & $\begin{array}{l}\text { Quality/installation } \\
\text { errors }\end{array}$ & $\mathbf{x}$ & & $\mathbf{x}$ & & & & $\mathbf{x}$ & & & $\mathbf{x}$ \\
\hline 3.0 & Simulated faeces & $\mathbf{x}$ & & & & $\mathbf{x}$ & & & & & $\mathbf{x}$ \\
\hline 4.0 & $\begin{array}{l}\text { Steep/variable } \\
\text { gradients }\end{array}$ & & $\mathbf{x}$ & & & & & $\mathbf{x}$ & $\mathbf{x}$ & & \\
\hline 5.0 & $\begin{array}{l}\text { Impact of wipes } \\
\text { on sewers }\end{array}$ & & & & & & & & $\mathbf{x}$ & $\mathbf{x}$ & \\
\hline 6.0 & White goods & & & $\mathbf{x}$ & & $\mathbf{x}$ & & & & & \\
\hline 7.0 & $\begin{array}{l}\text { Single occupancy } \\
\text { dwellings }\end{array}$ & & & $\mathbf{x}$ & & $\mathbf{x}$ & & & & & \\
\hline 8.0 & Baths versus showers & & & $\mathbf{x}$ & & & & & & & \\
\hline 9.0 & $\begin{array}{c}\text { The use of } \\
\text { non-circular pipes }\end{array}$ & & & & & & & & & $\mathbf{x}$ & \\
\hline 10.0 & $\begin{array}{l}\text { Degradation of } \\
\text { human faeces }\end{array}$ & & $\mathbf{x}$ & & & & & & & & \\
\hline 11.0 & Surfactant dosing & & & & $\mathbf{x}$ & & & & & & \\
\hline
\end{tabular}

Notes: Gap No. 5 should also look at "flushable" products and should define what "flushable" means. Gap No. 10 degradation of human faeces identified through collaborations Butler had within Davies et al. [51] and Digman et al. [81]. Bridge [35] also makes specific reference to further work on non-level invert junctions.

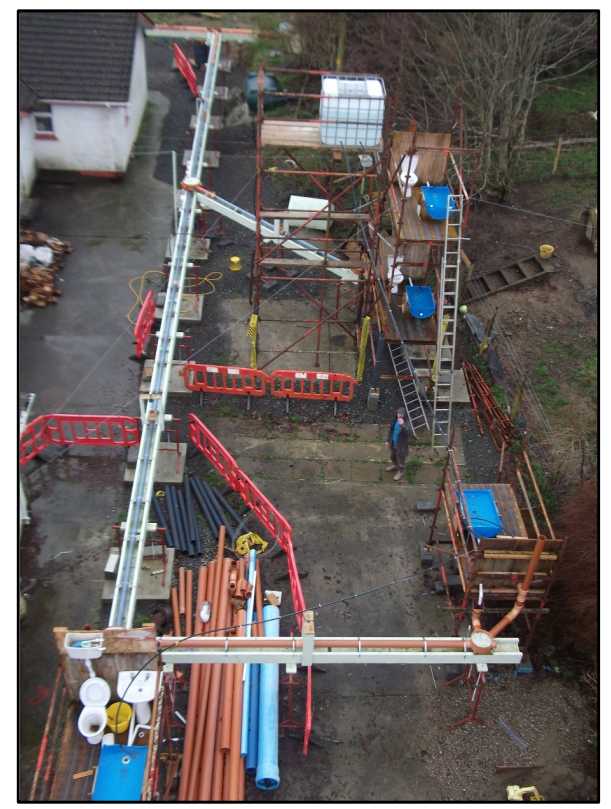

Figure 6. The McDermott test rig.

4) Revised foul sewer design for low flows: this study proposes revised foul sewer design guidance to cater for less water to waste.

5) Impact of single occupancy \& vacation periods on sewer blockages: this 
study reports on a 6-month simulation of houses with varying occupancy levels.

Whilst the above 5 research studies each address a gap in the current literature in the area of "low flow sewers", there is still a significant scope for future research to address all gaps identified by this paper.

A cross-party report has urged the UK Government to champion water efficiency in the built environment and specified a 100-litre water usage per person per day to make green infrastructure "the norm" [112]. This norm will lead to greater sewer blockages and requires building regulations to be revised to account for "less water to waste".

Solid Transfer in Low Flow Sewers, the Distance Travelled in terms of research so far is not enough. To judge that solid transfer research is complete can be compared to supporting a statement that "water conservation is complete".

\section{Conflicts of Interest}

The authors declare no conflicts of interest regarding the publication of this paper.

\section{References}

[1] Environment Agency (2008) Less Water to Waste. Environment Agency, Bristol.

[2] Environment Agency (2007) Conserving Water in Buildings. A Practical Guide. Environment Agency, Bristol.

[3] Swaffield, J.A. (2009) Closure-Dry Drain Forum. [Online] http://www.map-testing.com/assets/files/DryDrainsForum-2009-Dr.Swaffield-pt2-c losing.pdf

[4] Swaffield, J.A. (2009) Dry Drains: Myth, Reality or Impediment to Water Conservation. [Online] http://www.map-testing.com/assets/files/Swaffield-DRY-DRAINS-CIBW62-2009-p resentation.pdf

[5] Wakelin, R.H.M. (1978) A Study of the Transport of Solids in Hospital above Ground Drainage Systems. Ph.D. Thesis, Brunel University, Uxbridge.

[6] Bokor, S.D. (1982) Correlation of Laboratory and Installed Drainage System Solid Transport Measurements. Brunel University, Uxbridge.

[7] Lillywhite, M.S.T. and Webster, C.J.D. (1979) Investigations of Drain Blockages and Their Implications on Design. The Public Health Engineer, 7, 53-60.

[8] Lillywhite, M.S.T., Webster, C.J.D. and Griggs, J.C. (1987) Low-Water-Use Washdown WCs. Department of the Environment, Building Research Establishment, Building Research Station, Watford.

[9] Butler, D. (1991) A Small-Scale Study of Wastewater Discharges from Domestic Appliances. Journal of IWEM, 5, 178-185.

[10] Butler, D. (1992) Modelling the Variation of Domestic Dry Weather Flow in Sewer Networks. Ph.D. Thesis, Imperial College of Science and Technology, London.

[11] Butler, D. and Graham, N.J.D. (1992) Modelling Unsteady Domestic Dry Weather Flow in Sewers. International Conference on Unsteady Flow and Fluid Transients, Durham, 29 September-1 October 1992.

[12] Butler, D. (1993) The Influence of Dwelling Occupancy and Day of the Week on 
Domestic Appliance Wastewater Discharges. Building and Environment, 28, 73-79. https://doi.org/10.1016/0360-1323(93)90008-Q

[13] Butler, D. and Graham, N.J.D. (1995) Modelling Dry Weather Wastewater Flow in Sewer Networks. Journal of Environmental Engineering, 121, 161-173. https://doi.org/10.1061/(ASCE)0733-9372(1995)121:2(161)

[14] Butler, D., Littlewood, K. and Orman, N. (2005) Forces on Sanitary Solids in Small Sewers. Water Science \& Technology, 52, 85-92. https://doi.org/10.2166/wst.2005.0064

[15] Butler, D., Littlewood, K. and Orman, N. (2005) A Model for the Movement of Large Solids in Small Sewers. Water Science \& Technology, 52, 69-76. https://doi.org/10.2166/wst.2005.0112

[16] Swaffield, J.A. (1975) A Study of the Transport Waste Solids in above Ground Sanitary Drainage Systems. The Public Health Engineer, 17, 125-128.

[17] Swaffield, J.A. and Marriott, B.S.T. (1977) Hospital Drainage Design: A Study of Solid Transport in Steep Gradient Discharge Pipes. Brunel University, Uxbridge.

[18] Swaffield, J.A. and Marriott, B.S.T. (1978) An Investigation of the Effect of Reduced W.C. Flush on the Transport of Solids on above Ground Drainage Systems. CIBW62 Symposium on Water Supply and Drainage for Buildings, Belgian Building Research Institute, Brussels, October 1978.

[19] Swaffield, J.A. and Bridge, S. (1983) Wave Attenuation In Partially Filled Pipe Flow with Reference to Building Drainage Systems. 3 rd IPHE/Brunel Seminar on Drainage Design, Brunel.

[20] Swaffield, J.A. and Bridge, S. (1983) Applicability of the Colebrook-White Formula to Represent Frictional Losses in Partially Filled Unsteady Pipeflow. Journal of Research of the National Bureau of Standards, 88, 389-393. https://doi.org/10.6028/jres.088.019

[21] Swaffield, J.A., Wakelin, R.H.M. and Bocarro, R.A. (1986) Low Flush Volume W.C. Design for Developing Countries. Proceedings in CIB W62 Seminar, Copenhagen, 12-15 May 1986, 1-21.

[22] Swaffield, J.A., Wakelin, R.H.M. and Bocarro, R.A. (1989) Low Water Use Sanitation: The Design, Development and Appraisal of a Low Volume Flush Toilet in Botswana and Lesotho. Report, July, Overseas Development Agency, London.

[23] Swaffield, J.A. and Wakelin, R.H.M. (1976) Observation and Analysis of The parameters Affecting the Transport of Waste Solids in Internal Drainage Systems. Public Health Engineer, 4, November 1976, 165-170.

[24] Swaffield, J.A. and McDougall, J.A. (1995) Modelling Solid Transport in Building Drainage Systems. International Conference on Sewer Solids, University of Abertay, Dundee, 5-8 September 1995, 15-30.

[25] Swaffield, J.A. (2010) Transient Airflow in Building Drainage Systems. Taylor \& Francis, London. https://doi.org/10.4324/9780203879757

[26] Cummings, S., McDougall, J.A. and Swaffield, J.A. (2007) Hydraulic Assessment of Non-Circular-Section Building Drainage. Building Research \& Information, 35, 316-328. https://doi.org/10.1080/09613210601097913

[27] Cummings, S., Clark, J. and Barnard, L. (2009) Performance Compatibility of Water Efficient Fixtures with Drainage Systems and Plumbing Codes. [Online] http://www.map-testing.com/assets/files/DryDrainsForum-2009-Cummings-ClarkBarnard.pdf

[28] Cummings, S. (2010) Operational Performance Boundaries in Drainage Systems. 
[Online]

http://www.map-testing.com/assets/files/Cummings-2010-drainlineconnections-toil etpaper.pdf

[29] Littlewood (2000) Movement of Gross Solids in Small Diameter Sewers. Unpublished Ph.D. Thesis, Imperial College, University of London, London.

[30] Littlewood, K. and Butler, D. (2002) Influence of Diameter on the Movement of Gross Solids in Small Pipes. Proceedings of the International Conference on Sewer Operation and Maintenance SOM 2002, Bradford, 26-28 November 2002.

[31] Littlewood, K. and Butler, D. (2003) Movement Mechanisms of Gross Solids in Intermittent Flow. Water Science \& Technology, 47, 45-50. https://doi.org/10.2166/wst.2003.0217

[32] Littlewood, K., Memon, F.A. and Butler, D. (2007) Downstream Implications of Ultra-Low Flush WCs. 2nd International IWA Conference on Sewer Operation and Maintenance SOM, Vienna, 26-28 October 2006.

[33] Gauley, W. and Koeller, J. (2005) Evaluation of Low-Flush-Volume Toilet Technologies to Carry Waste in Drainlines (Final Report). Veritec Consulting Incorporated, Mississauga.

[34] Gauley, B. and Koeller, J. (2010) Sensor-Operated Plumbing Fixtures: Do They Save Water? California Energy Commission, Sacramento.

[35] Bridge, S. (1984) A Study of Unsteady Flow Wave Attenuation in Partially Filled Pipe Networks. Ph.D. Thesis, Brunel University, Uxbridge.

[36] Jack, L.B. and Swaffield, J.A. (2009) Embedding Sustainability in the Design of Water Supply and Drainage Systems for Buildings. Renewable Energy, 34, 2061-2066. https://doi.org/10.1016/j.renene.2009.02.009

[37] Jack, L.B., Swaffield, J.A. and Campbell, D.P. (2004) The Design and Specification of High-Rise Building Drainage Systems. Paper Presented at Proceedings of the CIB World Building Congress 2004 Canada, 1/01/70, 1-10.

[38] Jack, L.B., Swaffield, J.A. and Filsell, S. (2004) Identification of Potential Contamination Routes and Associated Prediction of Cross Flows in Building Drainage and Ventilation Systems. 30 th International Symposium on Water Supply and Drainage for Buildings, 62.

[39] Gormley, M. (2005) Mathematical Modelling of the Interaction of Multiple Solids in near Horizontal Drainage Networks. Ph.D. Thesis, Heriot-Watt University, Edinburgh.

[40] Kira, A. (1976) The Bathroom. Penguin. Viking Press, New York.

[41] Wyman, J.B., Heaton, K.W., Manning, A.P. and Wicks, A.C. (1978) Variability of Colonic Function in Healthy Subjects. Gut, 19, 146-150.

https://doi.org/10.1136/gut.19.2.146

[42] Wozasek, O. and Steigman, F. (1942) Studies on Colon Irritation. The American Journal of Digestive Diseases, 9, 423-425. https://doi.org/10.1007/BF02998161

[43] Boerner, F. and Sunderman, F.W. (1949) Faeces, Normal Values in Clinical Medicine. Saunders and Co., Philadelphia.

[44] Albritton, F.C. (1953) Standard Values in Nutrition Metabolism. WADC Technical Report. Wright Air Development Centre Wright-Patterson Air Force Base, Dayton.

[45] Gradwohl, R.B.H. (1956) Faeces. Clinical Laboratory Methods and Diagnosis, 2, 1261.

[46] Goldbith, S.A. and Wick, E.L. (1961) Analysis of Human Faecal Components and Study of Methods for Their Recovery in Space Systems. Wright Patterson Air Force 
Base, Aero-space Medical Laboratory, Dayton.

[47] Watson, C.J. (1936) Studies of Urobilinogen. I: An Improved Method for the Quantitative Estimation of Urobilinogen in Urine and Feces. American Journal of Clinical Pathology, 6, 458-475. https://doi.org/10.1093/ajcp/6.5.458

[48] Torondel, B. (2010) Sanitation Ventures Literature Review: On-Site Sanitation Waste Characteristics. Scientific Report. London School of Hygiene \& Tropical Medicine, London.

[49] Knoblauch, H.J. (1980) Fakazell, a New Test Medium to Simulate Reality in W.C. System Performance Evaluation. [Online] http://www.ircwash.org/sites/default/files/72DREG80-3466.pdf

[50] McDougall, J.A. and Swaffield, J.A. (2003) The Influence of Water Conservation on Drain Sizing for Building Drainage Systems. Building Services Engineering Research and Technology, 24, 229-243. https://doi.org/10.1191/0143624403bt074oa

[51] Davies, J.W., Butler, D., Small, J.L., Sekuloski, V. and Jefferies, C. (1998) Gross Solids Transport and Degradation. Water Science and Technology, 37, 61-68. https://doi.org/10.2166/wst.1998.0016

[52] Gormley, M. and Campbell, D.P. (2005) Airflow Distribution in Complex Building Drainage Networks: An Electrical Analogy to Aid Understanding. [Online] https://www.irbnet.de/daten/iconda/CIB12111.pdf

[53] McDougall, J.A. and Wakelin, R.H.M. (2007) The Influence of Flush Volume and Branch Drain Cross-Section on Deformable Solid Transport in Attenuating Flows. Building Services Engineering Research and Technology, 28, 7-22. https://doi.org/10.1177/0143624406070586

[54] Memon, F., Fidar, A., Littlewood, K., Butler, D., Makropoulos, C. and Liu, S. (2007) A Performance Investigation of Small-Bore Sewers. Water Science \& Technology, 55, 85-91. https://doi.org/10.2166/wst.2007.098

[55] Ackers, J.C., Butler, D. and May, R.W.P. (1996) Report 141. Design of Sewers to Control Sediment Problems. CIRIA, London.

[56] British Standards Institution (BSI) (2008) BS EN 752: 2008. Drain and Sewer Systems outside Buildings. BSI, London.

[57] McDougall, J.A. and Swaffield, J.A. (2000) Simulation of Building Drainage System Operation under Water Conservation Design Criteria. Building Services Engineering Research and Technology, 21, 41-51. https://doi.org/10.1177/014362440002100107

[58] BBC (2007) Flushed Bra Causes Sewer Collapse. [Online] http://news.bbc.co.uk/2/hi/uk_news/england/6766657.stm

[59] Fenner, R.A., Sweeting, L. and Marriott, M.J. (2000) A New Approach for Directing Proactive Sewer Maintenance. Proceedings of the ICE-Water and Maritime Engineering, 142, 67-77. https://doi.org/10.1680/wame.2000.142.2.67

[60] Rodríguez, J.P., McIntyre, N., Díaz-Granados, M. and Maksimović, Č. (2012) A Database and Model to Support Proactive Management of Sediment-Related Sewer Blockages. Water Research, 46, 4571-4586. https://doi.org/10.1016/j.watres.2012.06.037

[61] Park, H., and Lee, I. (1998) Existing Sewer Evaluation Results and Rehabilitation Strategies: The City of Seoul, Korea. Environmental Technology, 19, 733-739. https://doi.org/10.1080/09593331908616729

[62] Fenner, R.A. (1990) Excluding Groundwater Infiltration into New Sewers. Water and Environment Journal, 4, 544-551. 
https://doi.org/10.1111/j.1747-6593.1990.tb01468.x

[63] Arthur, S., Crow, H. and Pedezert, L. (2008) Understanding Blockage Formation in Combined Sewer Networks. Proceedings of the Institution of Civil Engineers - Water Management, 161, 215-221.

https://doi.org/10.1680/wama.2008.161.4.215

[64] Beattie, M. and Brownbill, D. (2007) The Trials and Tribulations of Reducing Sewer Blockages. Proceedings of 70 th Annual Victorian Water Industry Engineers and Operators Conference, Bendigo, 4-6 September 2007, 101-107.

[65] Purcell, P.J. (2003) Design of Water Resources Systems. Thomas Telford, London. https://doi.org/10.1680/dowrs.30985

[66] Marlow, D.R., Boulaire, F., Beale, D.J., Grundy, C. and Moglia, M. (2011) Sewer Performance Reporting: Factors That Influence Blockages. Journal of Infrastructure Systems, 17, 42-51. https://doi.org/10.1061/(ASCE)IS.1943-555X.0000041

[67] Water Branch (2011) Mandatory Adoption Arrangements for New Foul Sewers and Lateral Drains and Mandatory Build Standards for New Gravity Foul Sewers and Lateral Drains. Consultation. [Online] https://beta.gov.wales/sites/default/files/consultations/2018-01/111101mandatoryen pdf

[68] Fenner, R.A. (2000) Approaches to Sewer Maintenance: A Review. Urban Water, 2, 343-356. https://doi.org/10.1016/S1462-0758(00)00065-0

[69] Davies, J.P., Clarke, B.A., Whiter, J.T., Cunningham, R.J. and Leidi, A. (2001) The Structural Condition of Rigid Sewer Pipes: A Statistical Investigation. Urban Water, 3, 277-286. https://doi.org/10.1016/S1462-0758(01)00036-X

[70] Babaeyan-Koopaei, K., Butler, D. and Davies, J.W. (1999) Modelling of Gross Solids Transport in Sewers. Proceedings of the 8 th International Conference on Urban Storm Drainage, Sydney, 30 August-3 September 1999.

[71] Ashley, R., Blackwood, D., Butler, D., Jowitt, P., Davies, J., Smith, H., Gilmour, D. and Oltean-Dumbrava, C. (2008) Making Asset Investment Decisions for Wastewater Systems That Include Sustainability. Journal of Environmental Engineering, 134, 200-209. https://doi.org/10.1061/(ASCE)0733-9372(2008)134:3(200)

[72] Ashley, R., Blackwood, D., Butler, D., Davies, J., Jowitt, P. and Smith, H. (2003) Sustainable Decision Making for the UK Water Industry. Proceedings of the ICE-Engineering Sustainability, 156, 41-49. https://doi.org/10.1680/ensu.156.1.41.37058

[73] Energy Saving Trust (2013) At Home with Water. [Online] http://www.energysavingtrust.org.uk/sites/default/files/reports/AtHomewithWater \%287\%29.pdf

[74] Butler, D. (1991) A Small-Scale Study of Wastewater Discharges from Domestic Appliances. Journal of the Institution of Water and Environmental Management, 5, 178-185.

[75] Friedler, E., Brown, D.M. and Butler, D. (1996) A Study of WC Derived Sewer Solids. Water, Science and Technology, 33, 17-24. https://doi.org/10.2166/wst.1996.0166

[76] Parker, J.M. and Wilby, R.L. (2013) Quantifying Household Water Demand: A Review of Theory and Practice in the UK. Water Resources Management, 27, 981-1011. https://doi.org/10.1007/s11269-012-0190-2

[77] Laak, R., Healy, K.A. and Hardisty, D.M. (1974) Rational Basis for Septic Tank System Design. Groundwater, 12, 348-351. 
https://doi.org/10.1111/j.1745-6584.1974.tb03044.x

[78] Feachem, R.G., Bradley, D.J., Garelick, H. and Mara, D.D. (1983) Sanitation and Disease-Health Aspects of Excreta and Wastewater Management. John Wiley and Sons, Chichester.

[79] Friedler, E., Butler, D. and Brown, D.M. (1996) Domestic WC Usage Patterns. Building and Environment, 31, 385-392. https://doi.org/10.1016/0360-1323(96)00008-X

[80] Butler, D. and Davies, J. (2003) Urban Drainage. Spon Press, London.

[81] Digman, C.J., Littlewood, K., Butler, D., Spence, K., Balmforth, D.J., Davies, J. and Schütze, M. (2002) A Model to Predict the Temporal Distribution of Gross Solids Loading in Combined Sewerage Systems. Proceedings of the 9 th International Conference on Urban Storm Drainage, Portland, 28 September 2002, 1-13. https://doi.org/10.1061/40644(2002)102

[82] Ahyerre, M., Chebbo, G., Tassin, B. and Gaume, E. (1998) Storm Water Quality Modelling, an Ambitious Objective? Water Science and Technology, 37, 205-213. https://doi.org/10.2166/wst.1998.0050

[83] Arthur, S., Ashley, R.M. and Nalluri, C. (1996) Near Bed Solids Transport in Sewers. Water Science and Technology, 33, 69-76. https://doi.org/10.2166/wst.1996.0179

[84] Arthur, S., Ashley, R., Tait, S. and Nalluri, C. (1999) Sediment Transport in Sewers-A Step towards the Design of Sewers to Control Sediment Problems. Proceedings of the ICE-Water Maritime and Energy, 136, 9-19.

https://doi.org/10.1680/iwtme.1999.31264

[85] Arthur, S. and Ashley, R.M. (1998) The Influence of near Bed Solids Transport on First Foul Flush in Combined Sewers. Water Science and Technology, 37, 131-138. https://doi.org/10.2166/wst.1998.0032

[86] Baban, A. and Talinli, I. (2009) Modeling of Organic Matter Removal and Nitrification in Sewer Systems-An Approach to Wastewater Treatment. Desalination, 246, 640-647. https://doi.org/10.1016/j.desal.2008.07.018

[87] Banasiak, R., Verhoeven, R., De Sutter, R. and Tait, S. (2005) The Erosion Behaviour of Biologically Active Sewer Sediment Deposits: Observations from a Laboratory Study. Water Research, 39, 5221-5231. https://doi.org/10.1016/j.watres.2005.10.011

[88] Crabtree, R.W., Ashley, R. and Gent, R. (1995) Mousetrap: Modelling of Real Sewer Sediment Characteristics and Attached Pollutants. Water Science and Technology, 31, 43-50. https://doi.org/10.2166/wst.1995.0197

[89] Sakrabani, R., Vollertsen, J., Ashley, R.M. and Hvitved-Jacobsen, T. (2009) Biodegradability of Organic Matter Associated with Sewer Sediments during First Flush. Science of the Total Environment, 407, 2989-2995. https://doi.org/10.1016/j.scitotenv.2009.01.008

[90] Seco, I., Valentín, M.G., Schellart, A. and Tait, S. (2014) Erosion Resistance and Behaviour of Highly Organic In-Sewer Sediment. Water Science and Technology, 69, 672-679. https://doi.org/10.2166/wst.2013.761

[91] Tait, S.J., Rushforth, P.J. and Saul, A.J. (1998) A Laboratory Study of the Erosion and Transport of Cohesive-Like Sediment Mixtures in Sewers. Water Science and Technology, 37, 163-170. https://doi.org/10.2166/wst.1998.0040

[92] Verbanck, M.A., Ashley, R.M. and Bachoc, A. (1994) International Workshop on Origin, Occurrence and Behaviour of Sediments in Sewers Systems: Summary of Conclusions. Water Research, 28, 187-194. 
https://doi.org/10.1016/0043-1354(94)90133-3

[93] Stotz, G. (1984) Factors Affecting First Flushes in Combined Sewers. Proceedings of the 3 rd International Conference on Urban Storm Drainage, 4, S869-S878.

[94] Stotz, G. and Krauth, K.H. (1986) Depositions in Combined Sewers and Their Flushing Behaviour. Urban Drainage Management, 86, 443-453.

[95] Swaffield, J.A. and Galowin, L.S. (1989) Multi-Storey Building Drainage Network Design-An Application of Computer Based Unsteady Partially Filled Pipeflow Analysis. Building and Environment, 24, 99-110. https://doi.org/10.1016/0360-1323(89)90020-6

[96] Swaffield, J.A. and Galowin, L.S. (1992) The Engineered Design of Building Drain-age Systems. Ashgate, Aldershot.

[97] Swaffield, J.A. and Galowin, L.S. (1992) Investigation of Apparent Limits of Drainline Waste Transport with Low Volume Flush Water Closets. Proceedings of CIBW62 Symposium, Oporto, 20-23 September 1992, 253-266.

[98] Wise, A.F.E. and Swaffield, J.A. (1995) Water, Sanitary \& Waste Services for Buildings. 4th Edition, Longman Scientific and Technical, Harlow.

[99] Galowin L.S. (1979) Review of HUD/NBS Residential Water Conservation Conseil International du Bâtiment. CIBW62 Symposium, CSTB, Paris.

[100] Bertrand-Krajewski, J.L. (2003) Sewer Sediment Management: Some Historical Aspects of Egg-Shaped Sewers and Flushing Tanks. Water Science and Technology, 47, 109-122. https://doi.org/10.2166/wst.2003.0233

[101] Curthoys, M.C. (2009) Roe, John (1795-1874). Oxford Dictionary of National Biography. Oxford University Press. [Online] http://www.oxforddnb.com/view/article/100256

[102] Chadwick, E. (1842) Report on the Sanitary Condition of the Labouring Population of Great: Britain: Supplementary Report on the Results of Special Inquiry into the Practice of Interment in Towns. Volume 1. HM Stationery Office, London.

[103] Marriott, M.J. (1996) The Hydraulic Characteristics of Ovoid Sewers. Water and Environment Journal, 10, 365-368. https://doi.org/10.1111/j.1747-6593.1996.tb00065.x

[104] Swaffield, J.A. and Wakelin, R.H.M. (1996) Water Conservation: The IMPACT of design, Development and Site Appraisal of a Low Volume Flush Toilet. In: Mara, D., Ed., Low-cost Sewerage, Wiley, Chichester, 175-188.

[105] Ashley, R.M., Bertrand-Krajewski, J.L., Hvitved-Jacobsen, T. and Verbanck, M. (2004) Solids in Sewers: Characteristics, Effects and Control of Sewer Solids and Associated Pollutants. IWA Publishing, London.

[106] Gauley, W. and Koeller, J. (2003) Maximum Performance Testing of Popular Toilet Models. Final Report, Cooperative Canadian \& American Project. Veritec Consulting Inc., Mississauga; Koeller \& Co., Yorba Linda, CA.

[107] George, R. (2008) The Big Necessity: The Unmentionable World of Human Waste and Why It Matters. Metropolitan Books, New York.

[108] Gauley, W. (2014) (bill@gauley.ca), 6 April 2014. Re: Low Flow Research. Email to R. McDermott (r.mcdermott@ulster.ac.uk).

[109] Gormley, M. and Campbell, D.P. (2006) The Transport of Discrete Solids in above Ground near Horizontal Drainage Pipes: A Wave Speed Dependent Model. Building and Environment, 41, 534-547. https://doi.org/10.1016/j.buildenv.2005.02.017

[110] Plumbing Efficiency Research Network (PERC) (2012) The Drainline Transport of Solid Waste in Buildings. [Online] 
http://www.plumbingefficiencyresearchcoalition.org/wp-content/uploads/2012/12/ Drainline-Transport-Study-PhaseOne.pdf

[111] Office for National Statistics (2013) National Population Projections, 2012-Based Statistical Bulletin. [Online]

http://www.ons.gov.uk/ons/dcp171778_334975.pdf

[112] George, S. (2018) Cross-Party Report Urges Government to Champion Water Efficiency in Built Environment. [Online]

https://www.edie.net/news/4/Cross-party-report-calls-for-Government-to-embed-w ater-efficiency-in-planning-policy/\#\# 